\title{
THE FEASIBILITY OF ADAPTIVE REUSE OF VACANT INDUSTRIAL BUILDINGS IN SOUTHWESTERN ONTARIO
}

\author{
By \\ Kayly Robbins \\ BA, McMaster University, Hamilton, 2016 \\ A Major Research Paper \\ presented to Ryerson University \\ In partial fulfillment of the requirements for the degree of \\ Master of Planning \\ in \\ Urban Development \\ Toronto, Ontario, Canada, 2019
}

(C) Kayly Robbins 2019 


\section{AUTHOR'S DECLARATION}

I hereby declare that I am the sole author of this MRP. This is a true copy of the MRP, including any required final revisions.

I authorize Ryerson University to lend this MRP to other institutions or individuals for the purpose of scholarly research.

I further authorize Ryerson University to reproduce this MRP by photocopying or by other means, in total or in part, at the request of other institutions or individuals for the purpose of scholarly research.

I understand that my MRP may be made electronically available to the public. 


\title{
THE FEASIBILITY OF ADAPTIVE REUSE OF VACANT INDUSTRIAL BUILDINGS IN SOUTHWESTERN ONTARIO
}

\author{
By \\ (C) Kayly Robbins, 2019 \\ Master of Planning in Urban Development \\ Ryerson University
}

\begin{abstract}
This research investigated the feasibility of adaptive reuse of vacant industrial buildings in Southwestern, Ontario. Adaptive reuse is a conversion strategy that has recently been utilized in cities faced with a decline in industry. The cities experiencing a labour shift away from manufacturing now have dilapidated vacant or underutilized industrial buildings across their urban landscape. Adaptive reuse is the process of reusing an existing building, with or without changes to the structure, for a new purpose. Southwestern, Ontario is a region that has struggled to rebound from the economic shift, and the 2008/2009 recession. The region is located southwest of Toronto, bordering Lake Erie and Lake St. Clair. This study, through case study analysis, explored the characteristics that are important in hindering or facilitating the feasibility of adaptive reuse of existing vacant industrial buildings. The case studies demonstrate that location, market characteristics, legislation, council support, and financial implications are the most important factors in assessing the feasibility of adaptive reuse. This research, and the recommendations provided, may aid municipalities and counties in encouraging and working with developers to revitalise their vacant industrial buildings.
\end{abstract}

Key words: adaptive reuse, brownfield redevelopment, Southwestern Ontario 


\section{ACKNOWLEDGMENTS}

I would like to thank my supervisor, Professor Ronald Keeble, for his guidance and insight in the development and completion of this report.

I would also like to thank Professor Christopher De Sousa for being the Second Reader of my Final Draft Paper. 


\section{TABLE OF CONTENTS}

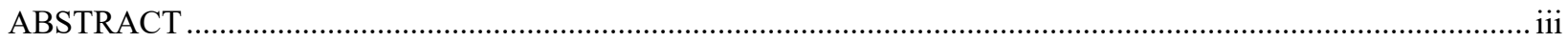

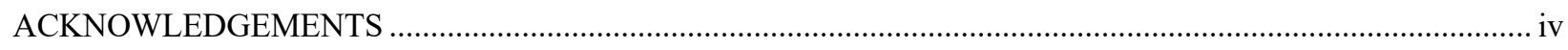

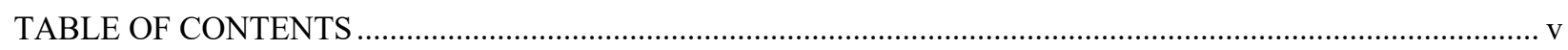

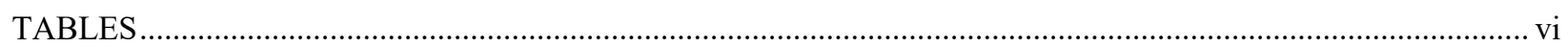

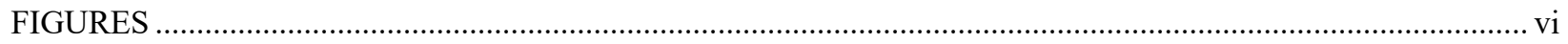

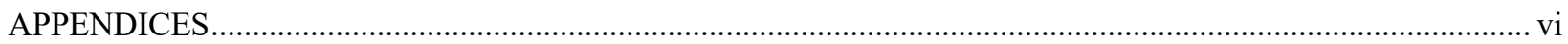

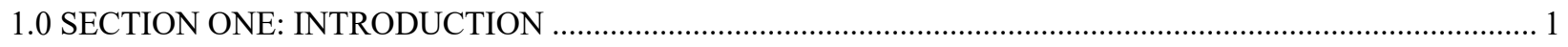

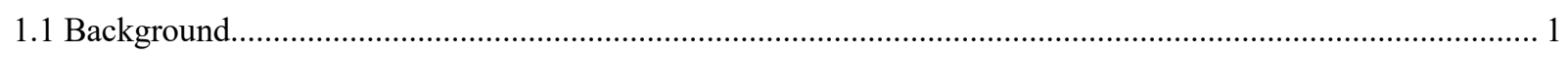

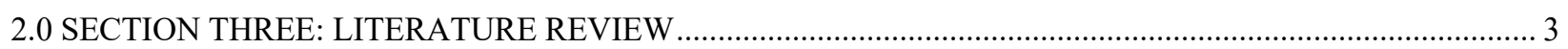

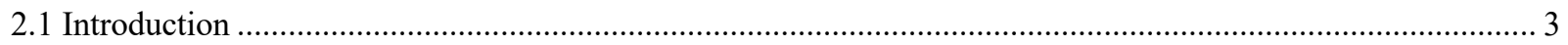

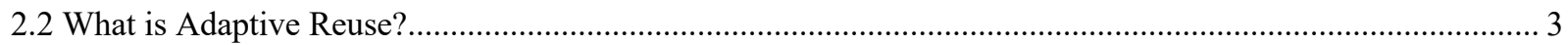

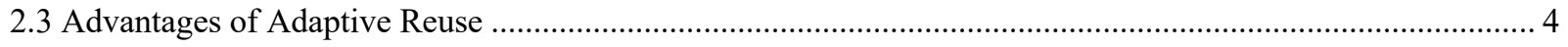

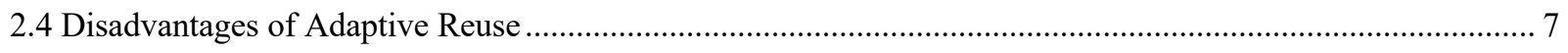

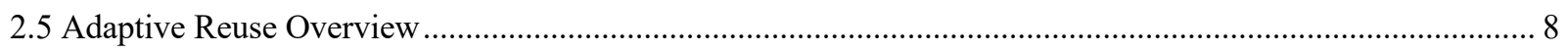

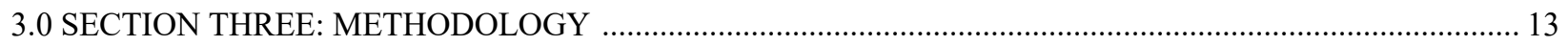

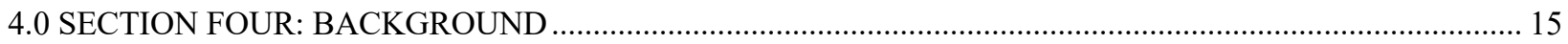

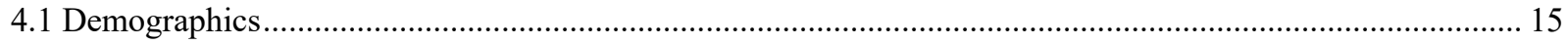

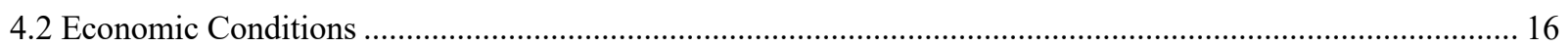

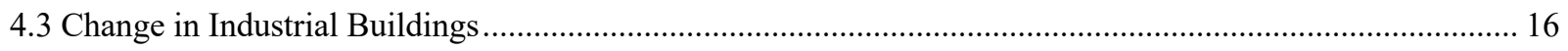

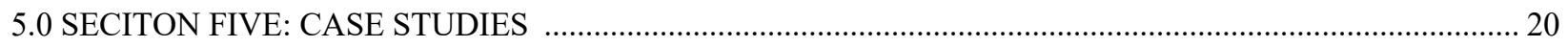

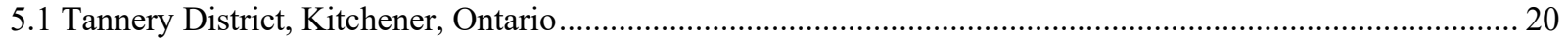

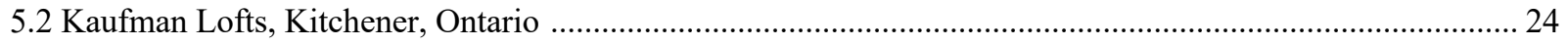

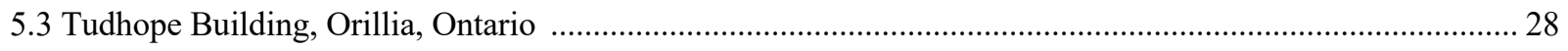

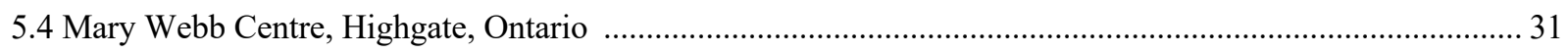

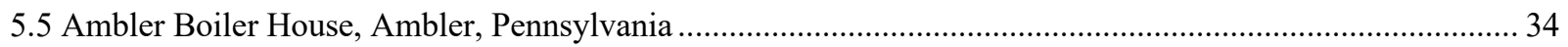

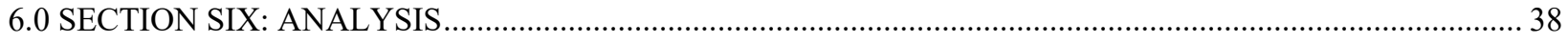

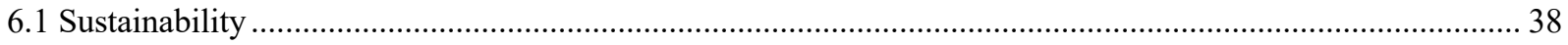

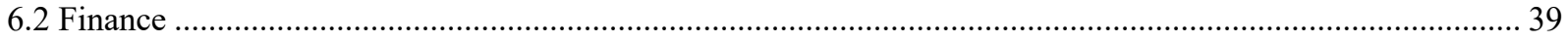

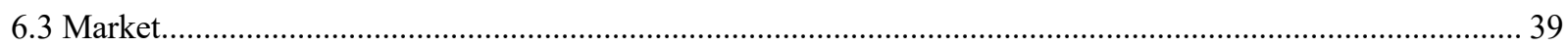

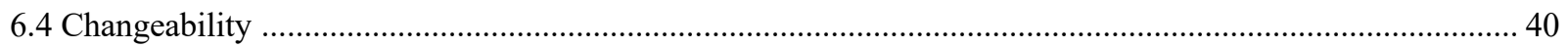

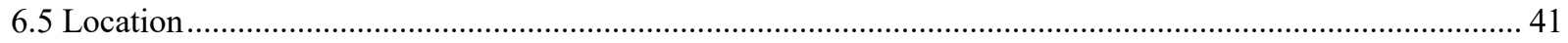

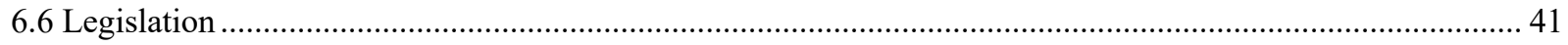

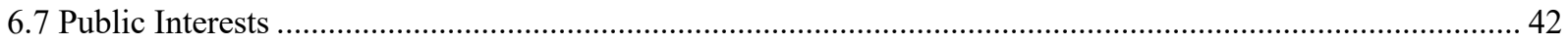

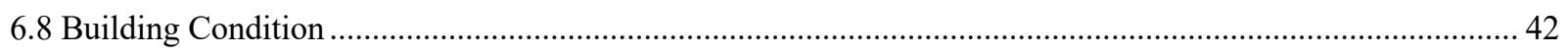

7.0 CHAPTER SEVEN: RECOMMENDATIONS AND CONCLUSIONS …...................................................... 43

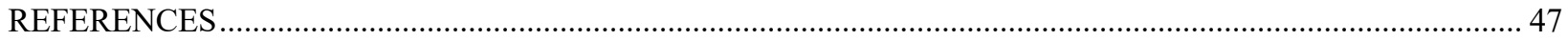




\section{TABLES}

Table 1. Population and population growth by geographic area (Statistics Canada, 2018) ..........15

\section{FIGURES}

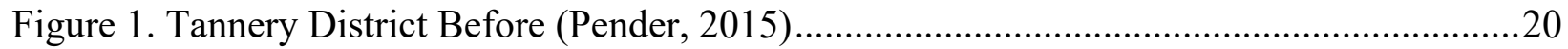

Figure 2. Tannery District After (Mora Masonry, 2019) ........................................................20

Figure 3. Kaufman Rubber Plant (Doors Closed Waterloo, 2013) ..........................................24

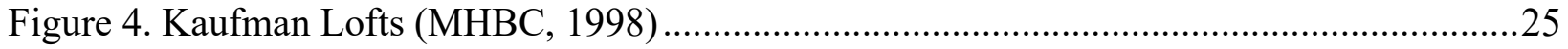

Figure 5.Tudhope Factory Before (Orillia Matters, 2018) ..................................................28

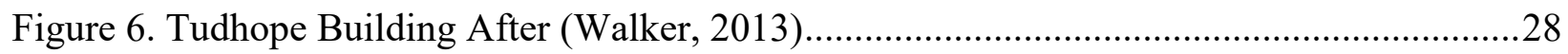

Figure 7. Highgate United Church (Blake, 2012) ....................................

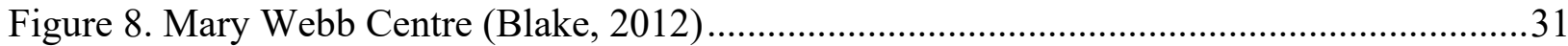

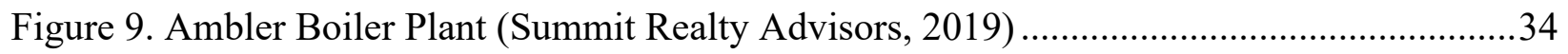

Figure 10. Ambler Boiler House (Summit Realty Advisors, 2019) .........................................34

\section{APPENDICES}

Appendix A: Southwestern Ontario Context Map......................................46 


\subsection{SECTION ONE: INTRODUCTION}

\subsection{Background}

The ongoing labour shift from manufacturing to services has resulted in specific regions experiencing an increased number of vacant or underutilized industrial buildings. There is also a growing responsibility of promoting and implementing sustainable practices within the built environment, especially in the form of urban regeneration schemes. These factors combined demonstrate the need to focus on policies and planning principles that offer economic, environmental and social benefits, such as adaptive reuse (Aigwi, Egbelakn \& Ingham, 2018; Tam \& Hao, 2018). Adaptive reuse is the process of reusing an existing building, with or without changes to the structure, for a new purpose (Douglas, 2006; Louw, 2015).

Adaptive reuse is a conversion strategy that has recently been utilized in cities faced with a decline in industry. The cities experiencing a labour shift away from manufacturing now have dilapidated vacant or underutilized industrial buildings across their urban landscape. Southwestern Ontario is a region that has struggled to rebound from the economic shift, and the 2008/2009 recession. The region is southwest of Toronto, bordering Lake Erie and Lake St. Clair. It is comprised of the following municipalities: London, St. Thomas, Windsor, Chatham, and Sarnia, Owen Sound, and Stratford, among many others. Once known as the economic driver of Ontario due to the high proportion of manufacturing jobs. Southwestern Ontario is now faced with derelict industrial buildings scattered across the urban landscape. The manufacturing sector is the dominant economic activity in Southwestern Ontario. Therefore, during the recession, the area saw the largest increase in unemployment as compared to the rest of the province (Eisen $\&$ Ames, 2016). Since the recession, Southwestern Ontario has experienced very little economic growth (Eisen \& Ames, 2016). The increase in unemployment in the area was a result of numerous manufacturing plants downsizing or shutting down operations. This left the communities with an abundance of vacant industrial buildings. The region should be focusing their efforts on encouraging redevelopment or conversion strategies that improve these sites to promote further revitalisation.

Other places, such as Toronto, have seen adaptive reuse projects take shape. Toronto is experiencing exponential growth and as such, developers are becoming more innovative with their projects. Adaptive reuse in Toronto has seen the conversion of industrial buildings for various uses, including residential lofts, community centres, office and live/work units, and 
mixed-use buildings. Adaptive reuse promotes recycling of materials, it limits energy consumption, and it is a growing trend in placemaking.

There are many advantages and disadvantages of embracing adaptive reuse, but it is situational. The success of an adaptive reuse project is context specific and does not inherently insinuate the next adaptive reuse application with succeed. There are numerous characteristics that have to be in place for an adaptive reuse project to be successful and this could explain why Toronto has seen adaptive reuse as a growing trend. There are characteristics in place that have allowed the majority of these projects to succeed. One of the most important being the market. There is a market for adaptive reuse in Toronto because there is a market for centrally located office space, community centres, and residential units. There is also a market for creative city building. These markets are less prominent in places outside of the Greater Toronto Area (GTA). Southwestern Ontario is very different from Toronto in terms of social, economic and environmental attributes, and is also not experiencing the same growth and development. The feasibility of revitalisation strategies in the Toronto context are not easily comparable to other contexts. The feasibility of using adaptive reuse on a blighted building depends on numerous factors, including location, market characteristics, policies, environmental conditions, and financial considerations.

This paper will explore the feasibility of adaptive reuse within Southwestern Ontario by analyzing case studies through the lens of various factors to determine specific indicators that impact the success and/or failure of adaptive reuse. This report will conclude by offering recommendations for local authorities to encourage the use of adaptation as a sustainable urban regeneration measure. 


\subsection{SECTION TWO: LITERATURE REVIEW}

\subsection{Introduction}

Adaptive reuse is not a new principle. It has been around for decades in varying degrees and forms. First widely recognized as a strategy to conserve historical monuments, the concept took off during the second half of the $20^{\text {th }}$ century when cities were faced with a decline in industry as businesses started moving outward to follow the progression of suburban living (Cantell, 2005). Since the second half of the $20^{\text {th }}$ century Canadian cities have been victim to seeing underutilized buildings across their urban landscapes. These trends became a catalyst for the development of new principles focusing on infill development and brownfield redevelopment. However, the impact of these policies and principles has been staggered. In cities with greater availability of greenfields, adaptive reuse is less likely to be a viable strategy, especially on a brownfield site. A brownfield site refers to undeveloped or previously developed properties that may be contaminated, usually former industrial or commercial properties that may be underutilized, derelict or vacant (Ministry of Municipal Affairs and Housing, 2007). The following section will review the concept of adaptive reuse and literature that evaluates the benefits and constraints of adaptive reuse.

\subsection{What is Adaptive Reuse?}

Adaptive reuse is the process of reusing a site or building for a different purpose from that which it was built for (Yung \& Chan, 2012). It is considered a method of preservation, conservation, rehabilitation, renovation and recycling (Tam \& Hao, 2018). Tam \& Hao (2018) also define it as "maximizing building life with changing the original building usage" (p. 2). It is used to improve the resiliency and sustainability of buildings. (Aigwi et al., 2018). The focus of adaptive reuse is to retain the original identity and structure of the building to exemplify the historic industrial character of the community (Cantell, 2005). It offers a chance to maintain the urban landscape by respecting the "roots and traditions" of a place (Petkovic-Grozdanovica, Stoiljkovic, Kekovic \& Murgul, 2016, p. 1837). Adaptive reuse can take many forms including minor alterations and repairs to the physical structure, additions, or major changes to the exterior or interior. Adaptive reuse is a strategy to improve blighted buildings that have failed economically or socially (Tam $\&$ Hao, 2018). Adaptive reuse considers the past, present and future of the building (Cantell, 2005). 
Adaptive reuse is an alternative to demolition. It is premised on the idea of reworking or altering a building for a new use. It is the process of completing repairs, alterations or additions while preserving portions of features of the original structure. The reuse of buildings demonstrates urban sustainability practices by avoiding demolition and reconstruction. There are advantages and disadvantages of applying adaptive reuse strategies to an underutilized building. The advantages and disadvantages will be explored within three categories: economic, social and environmental.

\subsection{Advantages of Adaptive Reuse}

Adaptive reuse offers developers and local authorities a choice to either convert an underutilized building or demolish the existing structure and build a new structure. The feasibility of converting an existing structure depends on numerous factors including the desired use, the costs associated with rehabilitation, the impact on the environment, and the concerns of the community.

\section{Economic}

One of the key economic benefits of adaptive reuse is that it increases the efficiency of the land market (Mesthrige, Wong \& Nga Yuk, 2018). This is supported by Manaf et al., (2013) who state that vacant land can disrupt the real estate market and it can lead to imbalances in urban development. Vacant land influences the development of land further away from the blighted and dilapidated sites therefore its presence adversely promotes outward growth and development on open spaces and farmlands (Hayek, Arku \& Gilliland, 2010). Typical underutilized or abandoned vacant sites are located in built-up areas with existing infrastructure and services. By adapting already existing buildings, the nearby infrastructure can be utilized.

Adaptive reuse is said to increase property values and property tax revenue (Mesthrige et al., 2018; Hayek et al., 2010). With rehabilitation, the site would have an increased property value, regardless of the use (commercial or residential), which consequently increases the local tax base for the local authority (Mohamed, Boyle, Yang, \& Tangari. 2017). For example, De Sousa, Wu, \& Westphal (2009) found an 11.4\% net increase in residential property near a brownfield redevelopment site in Milwaukee and a 2.7\% net increase for the same situation in Minneapolis. It is important to note that brownfield redevelopment also includes demolition and new build, it does not explicitly refer to adaptive reuse. In addition to an increase in property values and 
property tax, the reuse of vacant buildings has the potential of creating jobs (Yung et al., 2012; Cantell, 2005). Job creation can occur on the revitalized site, depending on the reuse, and in the surrounding community. A rehabilitated site promotes further revitalisation efforts in the community by attracting investment. Louw (2015) reported that conversion, compared to a new structure, contributes to more skill building and job creation. Adaptive reuse acts as a catalyst for future financial and social investment (Cantell, 2005).

Lastly, the costs associated with adapting an existing site compared to a new build is one of the most important factors for developers as their bottom line is to minimize costs and maximize profits. Ball (1999) reported the costs of reusing a vacant industrial building are lower than a new build; this was confirmed in a series of interviews with developers and related organizations who have experience in the industrial property market. Adaptive reuse saves the developer in construction costs both in terms of materials and actual time spent in the construction phase (Ball, 1999; Aigwi et al., 2018). Aigwi et al. (2018) also conducted interviews with development industry professionals in which $71 \%$ of respondents agreed adaptive reuse is cheaper compared to new construction. Cantell (2005) also reported that the construction costs associated with adaptive reuse projects are lower, and the cost of acquiring the land can be lower in some cases as industrial sites are not in high demand. However, it was noted that the cost of rehabilitating a vacant or underutilized building substantially depends on the condition of the building (Ball, 1999; Ball 2002; Cantell 2005; Hayek et al, 2010). Therefore, the experiences (i.e. cost savings) for one adaptive reuse is site specific and may not be applicable to other vacant sites.

\section{$\underline{\text { Environmental }}$}

An environmental benefit of adaptive reuse, and in some cases the most significant, is the retention of the embodied energy, which is all the energy consumed by the production of a building (Tam \& Hao, 2018; Louw, 2015). Adaptive reuse utilizes the transport, material use, and human energy that was once used for the creation of the original structure (Louw, 2015). The rehabilitation of a vacant building produces less waste, less resources, and reduces the need for materials and transport (Louw, 2015; Bullen \& Love, 2009). At a higher level, adaptive reuse is a form of infill development which is the intensification of land in existing built-up areas. Infill development, and in this case adaptive reuse, curbs urban sprawl (Cantell, 2005; Tam \& Hao, 2018). Urban sprawl is known to have significant adverse impacts on the environment such as increased dependency on vehicles emitting increased levels of carbon dioxide, it requires the 
outward expansion of services and infrastructure, which uses energy and materials, and lastly, urban sprawl consumes valuable agricultural land (Cantell, 2005; Tam \& Hao, 2018; Hayek et al., 2010).

The environmental benefits of adaptive reuse are important considerations when choosing to either rehabilitate an existing structure or construct a new building. Adaptive reuse is categorized within the realm of urban sustainability practices, smart growth, and resiliency as it utilizes an existing site and infrastructure. It extends the life of a building along with the embodied energy, and it improves the quality of life for the surrounding community.

\section{$\underline{\text { Social }}$}

Adaptive reuse offers social advantages to the local community that should not be overlooked in the development process. Schilling \& Logan (2008) identified that adaptive reuse of a vacant site can rebuild social capital by way of engaging residents in a collaborative planning process. Mesthridge et al., (2018) stated that community involvement in adaptive reuse projects can add social value to the properties. Vacant industrial properties predominantly offer large open spaces in the interior, which Yung \& Chun (2012) found to be ideal for a new tourist venue. However, Yung \& Chun (2012) noted public participation should be an important component of adaptive reuse projects considering the local community has created a sense of place with the current built environment, furthering the capacity to rebuild social capital.

Sense of place is one of the most significant social advantages of an adaptive reuse project (Louw, 2015). Sense of place is "the particular experience of a person in a particular setting" in which they feel comfortable, excited, and/or welcome (Steeles, 1981, pp. 1, in Cross, 2001). The reuse of a building helps local community members connect with their roots or their experiences working within the structures themselves. Cantell (2005) believes rehabilitation of industrial buildings maintains the historic industrial character of the community, he goes further in saying the architecture is impressive and therefore adapting the building recognizes its past, present and future. Integrating public participation in adaptive reuse projects also enhances the sense of place by allowing the citizens to feel their concerns and vision for their community is important (Yung \& Chun, 2012). 
Lastly, adaptive reuse promotes neighbourhood revitalisation by reversing the course of the broken-window theory. The broken window theory states that if a window in a building is broken, all the remaining windows will soon be broken (Schilling, 2002). It is premised on the idea that neglected and blighted sites signal a lack of caring to the community and it signals disorder and crime, deterring people from living and working in the surrounding neighbourhood (Schilling, 2002). Adapting neglected buildings has the capacity to create momentum in attracting investment, and encouraging further revitalisation measures (Ball, 1999; Schilling \& Logan, 2008).

\subsection{Disadvantages of Adaptive Reuse}

Adaptive reuse is a viable option for reducing the stock of underutilized and vacant industrial structures. However, it has its limitations in terms of financial considerations, environmental constraints, and social impacts. The following is an exploration of the constraints that deter developers and local authorities from focusing their efforts on rehabilitating neglected structures.

\section{Economic}

The costs associated with adaptive reuse are site-specific, and as mentioned, are generally less for converting an existing structure compared to constructing a new building. However, this is a contentious issue. The costs are site-specific in that each structure or site has the potential of being contaminated, in need of aggressive repairs or designed in a way that discourages effective rehabilitation. Hayek et al., (2010) found that little information exists regarding the costs associated with remediating contaminated sites, creating uncertainty for developers and local authorities. If remediation is required, adaptive reuse can be determined as being no longer feasible considering the ease of developing on greenfields. An additional economic consideration is the needed repairs for older structures to ensure it conforms to the applicable codes (Health and Safety, Fire, Building) and to ensure the building is energy efficient allowing for appropriate maintenance costs (Louw, 2015; Cantell, 2005).

\section{Environmental}

Much of the environmental concern of an adaptive reuse project is the unexpected condition of the building and/or site. When preparing a structure for rehabilitation, the developer could discover the site is contaminated or the building used asbestos product, or lead paint. Once discovered, this issue can be a burden on an adaptive reuse project because it could increase the 
costs substantially (Ball, 1999). The contaminated site is a major environmental concern but once discovered, becomes an economic concern. This is the only identified potential environmental constraint when considering converting an existing vacant building.

\section{$\underline{\text { Social }}$}

Adaptive reuse of a vacant industrial building can be a big undertaking, as it requires greater innovation and creativity. Hayek et al. (2010) found that a major hurdle of adaptive reuse, as opposed to new construction, is the lack of private sector participation. Many of the concerns listed above (unknown risks and associated costs) are the main reasons for the lack of private sector participation. Adaptive reuse projects are too big an undertaking for local authorities who lack the expertise and experience. It is in local authorities' best interest to assess their policies to ensure they are promoting projects that have economic, environmental and social benefits to the community.

The advantages and disadvantages of adaptive reuse are all important considerations for developers and local authorities in deciding whether to design and build, or promote the strategy, respectively. Through the above assessment of advantages and disadvantages, there are clearly more significant benefits than constraints when considering the feasibility of rehabilitating a building. However, a developer will choose the strategy (conversion or new construction) that maximizes profits. The main disadvantage of adaptive reuse is the potential for there to be added costs as a developer moves through the adaptive reuse process. The most important advantages of using adaptive reuse, are the saving of embodied energy, and the cultural significance of adapting a building with a history (Louw, 2015).

\subsection{Adaptive Reuse Overview}

Conversions of industrial buildings have become a solution in areas lacking the availability of greenfields and the desire to revitalize their blighted areas. Adaptive reuse is seen as a viable, creative option. Jevromovic et al., (2012) noted that simple, wide-open spaces of manufacturing sites "ignite the imagination of new generations who have been rescuing these buildings" (p. 85). Cantell (2005) shared the same enthusiasm for rehabilitation by stating "industrial complexes and buildings are impressive architecturally, both in their size and muted decorations" (p.4). Adaptive reuse allows for the creation of a new civilized space to work or live, in place of a blighted and neglected area (Lute \& Marincu, 2016). It provides cities with a resilient solution 
that has positive social, economic and environmental outcomes. Aigwi et al. (2018) see adaptive reuse as a strategy for urban decline in a specific place and time.

For adaptive reuse to be successful many different factors need to be considered. The study Critical Success Factors for the Adaptive Reuse of Industrial Buildings in Hong Kong examined various factors affecting adaptive reuse of industrial buildings. Tan, Shuai, \& Wang (2018) identified 33 factors, grouped into 8 categories: sustainability, finance, market, changeability, location and neighbourhood, culture and public interests, legal and regulatory markets, and the physical condition of the building. Similarly, Bullen and Love (2011) in their report A new future for the past: a model for adaptive reuse decision-making conducted interviews with industry professionals regarding the issues of adaptive reuse. They found three criteria that can be used to assess the feasibility of adaptive reuse: capital investment, asset condition, and regulation. The next subsection will analyze the principles set out by both Tan et al. (2018) and Bullen and Love (2011). The eight principles were also explicitly identified or referenced in some form through the analysis of the advantages of disadvantages of adaptive reuse. Within the environmental category, whether as an advantage or disadvantage, asset condition, changeability, and sustainability were identified as key considerations. Within the social category, the public interests, location, and legislation were explored as determinants of adaptive reuse. Lastly, the economic category identified market and financial conditions to be important. The use of these eight categories, sustainability, public interests, location, legislation, changeability, market, finances, and asset condition encompass the most pertinent factors of adaptive reuse. Therefore, these factors will guide the case study analysis.

\section{Sustainability}

Sustainability is used to measure the feasibility and success of adaptive reuse projects as one of the purposes of rehabilitating a building is to take advantage of the environmental benefits. Tan et al. (2018) found the sustainability category to include site layout, material consumption, construction waste and pollution, energy efficiency, and green design. Bullen and Love (2018) also identified that for a project to be successful, sustainability practices need to be considered. Adaptive reuse is born out of sustainable concepts, such as conservation, regeneration, revitalisation, and preservation. Consequently, sustainability is typically a guiding principle when assessing the feasibility of an adaptive reuse project. 


\section{Finance / Capital Investment}

By examining the advantages and disadvantages of adaptive reuse, it was apparent financing the rehabilitation of a building is a major consideration for developers. Within this category, Tan et al (2018) identified commercial risk and uncertainty, financial incentives, conversion cost, and ownership of building as important factors to be considered when determining if adaptive reuse is the best redevelopment option for a specific site. Bullen and Love (2018) identify the economic consideration to be the most important, as developers have a desire to make a profit. Through interviews with industry professionals it was concluded that if an adaptive reuse project was economically viable and an asset could be generated upon completion, it would be highly considered. However, as seen through reference to various literature, the costs are site specific and can change as the project gets underway.

\section{Market}

Market conditions determine the "potential need of adaptive reuse of industrial buildings" (Tan et al., 2018, p. 13). Market demand is vital for an adaptive reuse project to be successful (Ball, 2002). For it to be successful, the end use needs users, occupants, and/or tenants. The feasibility of an adaptive reuse project depends on the needs of the local community and the end use of the building (Tan et al., 2018). The developer will not consider rehabilitating a building if the end use lacks market demand and the ability to make sufficient profit.

\section{Changeability}

Changeability refers to the buildings ability to adapt to a new use (Tan et al., 2018).

Changeability encompasses multiple factors of the site, such as structural adaptability of the building, the capacity of the surrounding infrastructure to service the new use/uses, the layout of the building in relation to other buildings and uses, and the technological upgrades needed for the building (Tan et al., 2018). The ability of the structure to easily be adapted to a new purpose has been identified as one of the most important factors when considering the adaptive reuse of a vacant industrial building (Ball, 2002; Lute \& Marincu, 2016; Louw, 2015). This category is site specific and end-use specific; it is difficult to apply the ease of changeability as the structure, condition of the building, and site layout all vary from one project to another. 


\section{Location and Neighbourhood}

"The location of buildings has long been considered the most important factor for property development" (Tan et al., 2018, p. 14). The location and neighbourhood surroundings are a major determining factor in whether a vacant industrial building is converted to a new use or demolished for a new building. Industrial buildings were originally located in city and town centres, thus making them attractive for redevelopment measures (Ball, 1999). The location needs be considered within the context of local economic and social factors to understand how the new uses will interact with and impact the surrounding community (Ball, 2002).

\section{Culture and Public Interests}

As discussed through the analysis of the advantages and disadvantages, the adaptive reuse of industrial buildings can preserve the history and sense of place of a community (Tan et al., 2018; Yung and Chan, 2012; Tam and Hao, 2018). The adaptation of a building should consider the needs of the community and the value of the building to the community. Aigwi et al., (2018) stated adaptive reuse has the potential to increase the quality of life and vibrancy of a community, and the new purpose should exemplify local needs. Public participation is integral for an adaptive reuse project to understand the public interest and address the constraints and challenges of adapting a building for a new use (Yung and Chan, 2012).

\section{$\underline{\text { Legal and Regulatory Markets }}$}

Adams et al., (2010) identified regulatory mechanisms to be a main concern for brownfield development, which includes adaptive reuse of vacant industrial buildings, as also reported by Louw (2015). Interviews conducted by Yung and Chan (2015) found the cost and time of regulatory processes can determine an adaptive reuse project as inefficient. Government assistance programs can help improve the legislative processes to ensure the required approvals are not discouraging the adaptation of vacant industrial buildings (Yung and Chan, 2015). The legislative processes put forth by municipal authorities can impact the financial implications and final uses of an adaptive reuse project. The regulatory environment is considered an important component of assessing the feasibility of converting a vacant industrial building. 


\section{Condition of Building / Asset Condition}

Lastly, an important factor in determining the viability of an adaptive reuse project is the condition of the building. The physical condition of a building impacts the costs and the ability of the building to adapt to a new use (Tan et al., 2018; Bullen and Love, 2011). Bullen and Love (2011) identified situations where the building would either cost a significant amount of capital to take on a new use or where the building would not actually lend itself to adaptation including a prison and a low-rise building that does not fully utilize the parcel and zoning regulations. Ball (2002) also stated that the age, condition, heritage value, size, accessibility and design all need to be taken into account in determining if the building is worth converting to a new desired use.

The above categories are the main factors analyzed in determining the feasibility of an adaptive reuse project. Tan et al., (2018) considered eight factors: sustainability, finance, market, changeability, location and neighbourhood, culture and public interests, legal and regulatory markets, and the physical condition of the building to be important. Bullen and Love, (2011) identified only three: asset condition, regulatory environment, and capital investment. A similar paper to this one, Adaptive Reuse of Vacant Industrial Buildings in Toronto, Ontario used the following five categories: legislative, location, environmental, financial, and market (Wilson, 2010). Section five will assess the case studies using the following eight factors: market, finance, changeability, location, public interests, legislation, asset condition, and sustainability. 


\subsection{SECTION THREE: METHODOLOGY}

The purpose of this paper is to assess the feasibility of adaptive reuse in Southwestern Ontario, an area that is in need of strategies to improve their vacant and underutilized sites. This paper explores adaptive reuse as a development principle. The identification of the disadvantages and advantages of adaptive reuse within the categories of economic, social or environmental provides the background necessary to understand the concept and the context of this report. The literature review was informed by secondary research through the use of journal articles, and government and institutional publications.

The methodology for this report focuses on assessing five case studies through eight key factors found through the literature review as being pertinent characteristics to adaptive reuse projects. These case studies have all successfully adapted industrial buildings, except in one case study where the building was originally a church. The case studies chosen best reflect the economic and demographic characteristics of Southwestern Ontario, which are explored in the following section. The case studies either reflect the small-to-mid size city that encompasses all of Southwestern Ontario or displays a similar industrial past as many of the cities in the region. The assessment of the case studies identifies the conditions that hinder or facilitate the success of an adaptive reuse project.

The assessment of the case studies is based on the information found within the literature review. These eight factors, sustainability, asset condition, location, public interests, sustainability, finances, market, legislation, and changeability were identified by Tan et al (2018) as being the main characteristics in determining the feasibility of adaptive reuse. Similarly, Bullen and Love, (2011) identified three of these eight and Wilson (2010) identified five of these eight. Therefore, to best analyze these case studies, all eight factors were used. This also allows a greater range of information to be gathered, organized and assessed.

The analysis of the case studies demonstrates the particular factors associated with adaptive reuse that have the greatest impact on the feasibility of adaptation. The analysis will explicitly examine and evaluate the economic, social, and environmental conditions through the lens of the eight categories to provide final recommendations to local authorities in Southwestern Ontario. The recommendations will focus on the programs, incentives, policies, market conditions, 
sustainability components, and conditions their blighted buildings need to be in for adaptive reuse to be viable.

The recommendations will allow municipalities to better foster adaptive reuse as a redevelopment strategy for their derelict structures and blighted sites. The recommendations speak to the characteristics of successful adaptive reuse projects. The recommendations provide municipalities located in Southwestern Ontario with information that will allow them to make progress in revitalising their struggling areas. These recommendations are influenced by the literature review and precedent research.

The purpose of this paper is to answer the following questions:

- What are the characteristics that hinder or facilitate the success of adaptive reuse projects?

- What can municipalities do to promote adaptive reuse of their derelict structures?

- Is adaptive reuse feasible in Southwestern Ontario? 


\subsection{SECTION FOUR: BACKGROUND}

\subsection{Demographics}

Southwestern Ontario is the area southwest of Toronto, bordering Lake Erie and Lake St. Clair. This geographic classification of Southwestern Ontario was influenced by a study published by the Fraser Institute (Eisen and Ames, 2016) in which they analyzed all five regions in Ontario (Southwestern Ontario, Greater Golden Horseshoe, Eastern Ontario, Ottawa and Surrounding Area, and Northern Ontario) and their labour market performance post-recession. Please refer to Appendix A for a map depicting the area. The region is comprised of 10 counties, as are identified in Table 1. The population in Southwestern Ontario in 2016 was 1,580,459 (Statistics Canada, 2018). Table 1 identifies the population by county and the population growth from 2011-2016. The population of Southwestern Ontario is second largest of the five regions, accounting for $11.7 \%$ of the total population. The Greater Golden Horseshoe is the largestaccounting for $66.7 \%$ of the population of Ontario (Eisen \& Emes, 2016). The analysis and summary of the region will be informed through County information - as very little literature exists that explores Southwestern Ontario, especially considering its boundaries are ambiguous. However, the report produced by the Fraser Institute will inform much of the analysis of Southwestern Ontario.

\begin{tabular}{|l|l|l|}
\hline Geographic Area & Population & Population change from 2011-2016 \\
\hline Essex County & 398,782 & $2.60 \%$ \\
\hline Lambton & 126,199 & $0.30 \%$ \\
\hline Chatham-Kent County & 102,042 & $-2.00 \%$ \\
\hline Middlesex County & 455,526 & $3.70 \%$ \\
\hline Oxford County & 110,862 & $4.90 \%$ \\
\hline Elgin County & 88,978 & $1.70 \%$ \\
\hline Bruce County & 68,147 & $3.10 \%$ \\
\hline Huron County & 59,297 & $0.30 \%$ \\
\hline Perth County & 76,796 & $2.20 \%$ \\
\hline Grey County & 93,830 & $1.40 \%$ \\
\hline Total & $1,580,459$ & \\
\hline
\end{tabular}

Table 1. Population and population growth by geographic area (Statistics Canada, 2018) 


\subsection{Economic Conditions}

The regions created by Eisen and Ames (2016) were created based on commuting patterns, geographically proximate locations, economic types, and common usage by residents which refers to the way residents define where they live and work. "Southwestern Ontario was historically an engine of economic growth in Ontario, powered by vibrant manufacturing and food-processing industries" (Eisen \& Ames, 2016, p. 5). A special report by Radwanski (2018) published in the Globe and Mail also identifies Southwestern Ontario as the "industrial heart of the nation" (para. 13). However, this status of a place of employment and industrial vibrancy has vanished. Since the 2008/2009 economic recession, and a few years leading up to it, Southwestern has seen decreases in employment. From 2008-2009 total employment fell by $5.0 \%$ which was the highest rate among all the regions in Ontario (Eisen \& Ames, 2016). Additionally, the unemployment rate during this period grew from $7.1 \%$ to $10.3 \%$ which is still the highest rate among in Ontario (Eisen \& Ames, 2016). Radwanski (2018) found that in a span of 10 years (2004-2014) Southwestern Ontario lost 25\% of their manufacturing jobs. Eisen and Ames (2016) examined how the five regions have performed since the recession. Between 2010 and 2015, Southwestern Ontario only averaged an annual growth in employment of $0.4 \%$, compared to the Greater Golden Horseshoe that experienced a growth in employment of $1.8 \%$ (Eisen and Ames, 2016).

The above information paints a picture of the current economic situation in Southwestern Ontario. The purpose here is not to provide an in-depth analysis of the current labour market of Southwestern Ontario. The purpose is to demonstrate, at a high-level, the experiences that have led the region to be left with blighted and underutilized sites across the urban landscape. With the shift from manufacturing to the service sector, and the movement of manufacturing out of the western world to developing countries with cheaper labour, Southwestern Ontario is no longer capable of competing for manufacturing investment the way the area once did.

\subsection{Change in Industrial Buildings}

Given the demise of the manufacturing sector in Southwestern Ontario, there is a large number of vacant industrial buildings scattered across the region. Industrial buildings were originally located in central business districts, as it offered access to materials and labour. Over time, suburban development proved to be more advantageous with lower property rates and a greater abundance of space. This shift of resources and labour from the inner city to the suburbs has 
resulted in vacant industrial buildings being located sporadically throughout Southwestern Ontario. For example, in 2013 the City of London's realty services division listed 79 vacant industrial buildings for lease or sale (Bernier, 2013). In a more recent publication, it was identified London has over 100 vacant properties in the downtown (De Bono, 2018). In St. Thomas there are over a dozen vacant industrial buildings, amounting to 700,000 square feet of empty real estate (Bernier, 2013). Although it is clear there is a large stock of vacant and derelict industrial buildings in Southwestern Ontario, progress has been made by local authorities to attract new occupants to these buildings.

The local authorities have taken note of the high numbers of vacant industrial structures and thus, have been making efforts to attract new occupants. Since the recession, in St. Thomas, 146,000 square feet building, 100,000 square feet building, and a 90,000 square feet building have been reoccupied, plus another 800,000 square feet of industrial space (Bernier, 2013). Southwestern Ontario has been working to improve their conditions. However, the new companies moving into the vacant industrial buildings are not producing the same amount of jobs that were once offered from these sites (Radwanski, 2018). By focusing efforts on attracting additional manufacturing uses to these buildings, local authorities are ignoring the potential of adapting these sites to new uses that could better serve the community, by way of housing, employment, or local gathering spaces. Some of the vacant industrial sites are located close to resources, such as transport routes, labour forces, suppliers and markets; this offers a great opportunity for redevelopment. These buildings were the economic drivers of this region, and for that they have a physical, historical and cultural link to the community. Therefore, it is logical from a social perspective, economic and environmental perspective to reuse these structures by way of adapting them to a new use that provides a greater benefit to the community. However, for a revitalisation project to be successful or have the opportunity to be successful, the environmental, social and economic conditions need to be assessed.

Adaptive reuse projects have been occurring throughout the world, especially since the decline of heavy industry during the mid to late $20^{\text {th }}$ century. Cantell (2005) suggests the decline of heavy industry has left blighted and underutilized vacant sites throughout Canada. In some regions that are experiencing high growth rates, adaptive reuse is a growing trend. Former industrial sites are being adapted to art studios, shared workspaces, residential units, schools, offices and mixed-use buildings. 
A recent exploration of adaptive reuse of vacant industrial buildings in Toronto identified eight case studies in which conversions have been successful (Wilson, 2010). Through this study, certain characteristics were concluded to be crucial in determining the feasibility of adaptive reuse. Location was noted as an important consideration, more specifically the downtown location was crucial. The surrounding conditions of the site were not seen as a major issue those sites located in lower income and well-established neighborhoods both saw successes. In terms of legislative matters, no factors were detrimental to the feasibility of adapting a site, it was noted that incentives such as increasing the gross floor area could boast well in encouraging converting vacant buildings (Wilson, 2010). One of the most important considerations identified was the market considerations. It stated adaptive reuse of vacant industrial structures is a strong market in Toronto, going as far as comparing it to the standard commercial and residential market (Wilson, 2010). Lastly, in terms of environmental characteristics, the architectural conditions are one of the deciding factors on part of the developers in choosing to revitalize a vacant building (Wilson, 2010). Certain qualities, such as tall ceilings, large windows, open space, and overall character were identified as being the most attractive for adaptive reuse (Wilson, 2010). Industrial buildings architecture, the size, open space, and muted decorations, can encourage innovation and creativity in terms of converting the building to a new use.

There are two major takeaways from this succinct exploration of the adaptive reuse applications in Toronto. The first being market considerations may be the most important characteristics in assessing the feasibility of an adaptive reuse project. Secondly, the market conditions in Southwestern Ontario are vastly different than Toronto - thus explaining why adaptive reuse has not gained the same momentum in Southwestern Ontario. Green (2012) shared the same concern for smaller locales, in saying they do not have the strong market forces that have influenced this type of redevelopment in major cities.

In recent years, intensification and adaptive reuse strategies have become a primary form of revitalisation in central locations. These strategies should play a larger role in Southwestern Ontario as vacant industrial buildings represent a significant portion of their urban landscape. Adaptive reuse strategies offer an opportunity to maintain the urban landscape and provides a chance for innovative revitalisation and renewal (Walljes \& Ball, 1997). It is clear that the feasibility of adaptive reuse is situational, in that it may not be the best strategy in every place 
with an abundance of vacant industrial properties. Small towns have a harder time in their efforts to revitalize delipidated areas and buildings (Cantell, 2005). The following case studies will provide examples of adaptive reuse projects in mid to small size cities that could be considered comparable to places in Southwestern Ontario. By analyzing and identifying the various characteristics of successful adaptive reuse projects, an assessment will be completed to understand how the case studies translate to opportunities for cities such as London, Windsor, Sarnia, Woodstock, St. Thomas, etc., in their efforts to overcome barriers to revitalize their declining sites and areas. 


\subsection{SECTION FIVE: CASE STUDIES}

\subsection{Tannery District, Kitchener, ON}

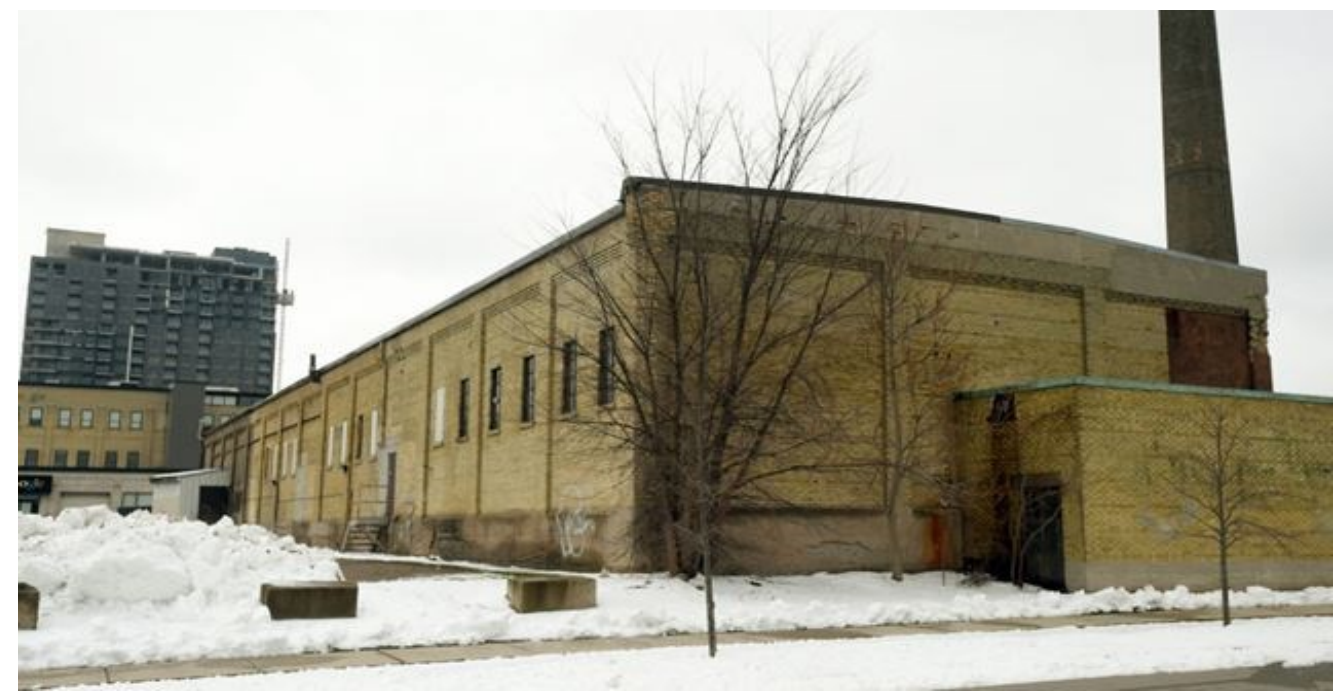

Figure 1. Tannery District Before (Pender, 2015)

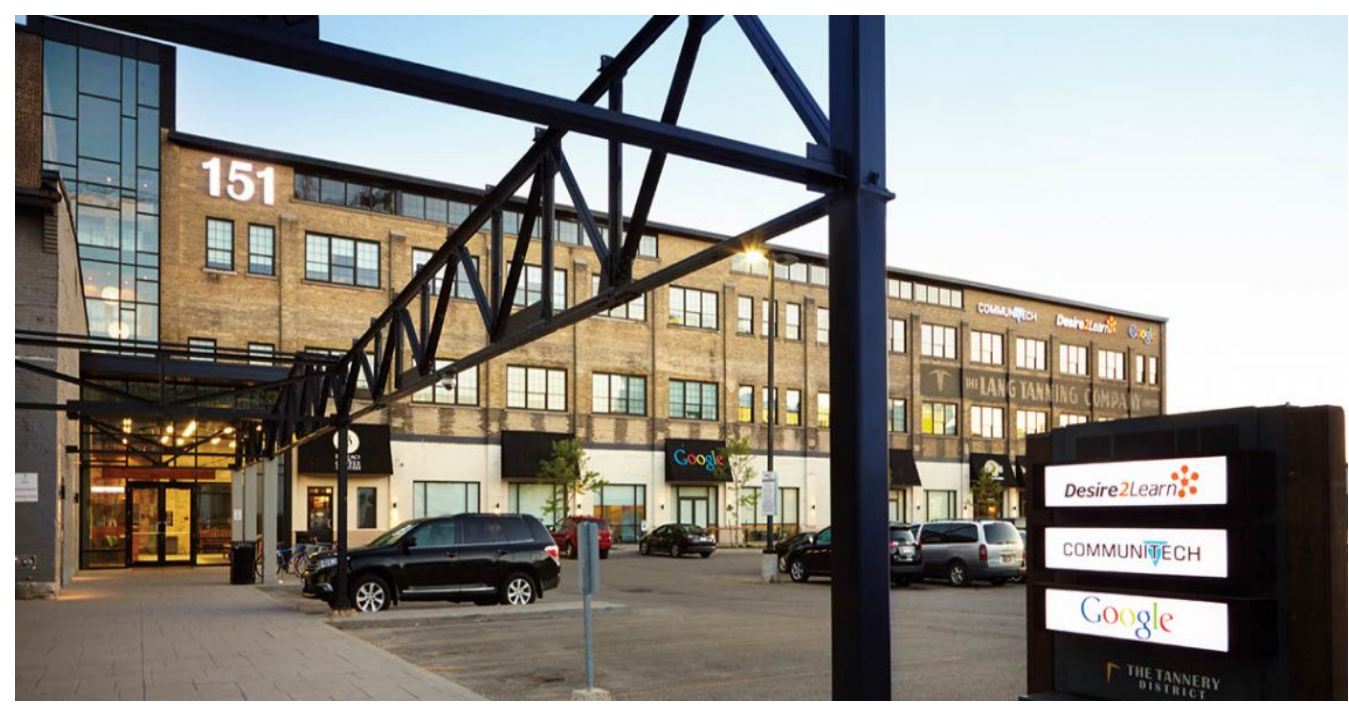

Figure 2. Tannery District After (Mora Masonry, 2019)

\section{Project Overview}

The Tannery District in Kitchener, Ontario is an example of adaptive reuse of an industrial building. The original occupant, the Lang Tanning Company, was once the largest leather producer in the British Empire. Most of the buildings were built between 1896 and 1917 with alterations and additions taking place in 1917 and 1925 (Evergreen Brickworks, 2017). The district was earmarked as a centre of industrial activity (Evergreen Brickworks, 2017).

Originally, more buildings existed than are present today - four buildings were demolished to 
make way for surface parking lots. The site was rehabilitated to a high-tech office space with tenants such as Desire2Learn, Google, Communitech, and a number of start-ups (Debrone, n.d.).

\section{Sustainability}

Much of the sustainability aspects of an adaptive reuse project are represented in the site layout and rehabilitation characteristics. This category is analyzing how sustainability practices were integrated into the adaptation of the building. The Tannery District in Kitchener is an environmentally friendly and sustainable development, so much so it has won a brownie award (an award given for successful and impactful brownfield redevelopment projects) for innovation and environmental sustainability. Unfortunately, information is unavailable regarding the level of sustainability of the revitalisation, but it is evident the redevelopment of this industrial site has contributed positively to the environment, and the community.

\section{Finance}

The site was originally purchased in 2007 for 9.5 million by Cadan Inc., a Toronto based company familiar with brownfield development (Evergreen Brickworks, 2017). The redevelopment costs amounted to approximately $\$ 30$ million (Evergreen Brickworks, 2017). A joint partnership was created between Cadan Inc., City of Kitchener, and Region of Waterloo for the remediation portion of the project. All partners contributed to the clean-up costs. The City of Kitchener made plans to reimburse $\$ 891,000$ over a ten-year period to Cadan Inc., the amount of funding contributed by the Region of Waterloo for the remediation are unknown (City of Kitchener \& Region of Waterloo, 2016). The City of Kitchener also waived all development charges and parkland dedication fees for the project. The Tannery is for-profit, therefore has been able to earn a profit from the tenants who pay market rent.

\section{Market}

Prior to the completion of the project, Cadan Inc. was aware Communitech was interested in occupying space in the revitalized building and therefore Cadan Inc. knew demand for the space existed. This informal agreement, along with determining a market exists for high tech to align with old architecture allowed this project to succeed (Evergreen Brickworks, 2017). Due to the recession, the property was also purchased at a time when property values were low. By the time the project was nearing completion, the market was more suitable with a better return on 
investment. However, it should be emphasized that representatives from Cadan Inc. said a market is necessary, as well as an understanding of the needs of future occupants (Debrone, n.d.).

\section{Changeability}

Changeability refers to the buildings ability to adapt to a new use. Given the scale of the site, the developer had to assess the multiple buildings to decide which structures and components they wanted to preserve, utilize, and/or renovate. The physical buildings offer large open space - a desirable component for the end use. Large open space also allows for greater creativity. The main alterations and improvements to the site include repointing the deteriorated masonry joints, replacement of deteriorated bricks, roof repairs, repair of existing windows, installation of new windows of complementary design, and installation of new doors and windows (City of Kitchener, n.d.). The brick and wood from the original buildings that were demolished were reused, and the additions generally used material such as metal and glass to demonstrate the mixture of old and new (City of Kitchener, n.d.).

\section{Location/Neighbourhood}

The Tannery district is located in downtown Kitchener. For many years, Kitchener was compared to its neighboring city Waterloo, the comparison thought of Kitchener as place that was left behind when Waterloo experienced exponential growth in the tech industry (Evergreen Brickworks, 2017). Therefore, the City of Kitchener began implementing revitalisation strategies to attract similar growth and economic development that was occurring in Waterloo. The redevelopment of the Tannery district was a major redevelopment project that had the potential of spurring growth and encouraging further revitalisation of Downtown Kitchener. The site was chosen based on its central location in Kitchener and the site characteristics. The City of

Kitchener was able to invest in the Tannery District because of the downtown location by providing assistance to potential tenants to help improve demand for office space (Evergreen Brickworks, 2017). The City also influenced the University of Waterloo to locate the new School of Pharmacy, the Wilfrid Laurier School of Social Work, and later the McMaster University Michel De Groote School of Medicine, and the University of Waterloo regional campus in the downtown area. Given the initial investment from Cadan Inc. and the support from the City of Kitchener, the area is now known as the Innovation District, with almost 500 startups located within a couple kilometers from the site (Evergreen Brickworks, 2017). The area is also now 
experiencing the growth of condominiums to accommodate the employment increase. The success of the Tannery District can, in part, be attributed to the central location.

\section{Public Interests}

This project had a significant community outreach component to it. For starters, the City was made aware of the project at an early stage, which allowed them to form a joint partnership for the remediation stage (Evergreen Brickworks, 2017). The two parties also worked together to ensure they each benefitted from the project. The City of Kitchener was aware of the benefits a project like this can bring to the neighbourhood and city, and therefore they were willing and eager to promote further investment into the area (City of Kitchener \& Region of Waterloo, 2016). Cadan Inc. also reached out to the public to engage with them about the redevelopment plans, and to gain insights into the expectations that the potential tenants and users of the site may have. The informal agreement between Cadan Inc. and the future occupant of the site, Communitech, demonstrated a high level of engagement and cooperation. Cadan Inc. wanted to create facilities that reflected the tech industry and could attract further investment.

\section{$\underline{\text { Legislation }}$}

The City of Kitchener in partnership with the Region of Waterloo implemented a brownfield financial incentive program which provides a tax increment grant to advocate for urban renewal of the downtown neighbourhood. The grant is to assist owners with the remediation and redevelopment of brownfield sites (City of Kitchener \& Region of Waterloo, 2016). For those receiving the grant, the owner must form a legal agreement with the City of Kitchener and the Region of Waterloo outlining the criteria and responsibilities of each party (City of Kitchener \& Region of Waterloo, 2016). The brownfield financial incentive program also helps owners through the planning approvals process which can result in quicker approvals and subsidized costs - as is the case for the Tannery District.

The proposed use of the redeveloped site complimented the policies set forth in the City of Kitchener Official Plan and Zoning By-law (Sugden, 2017). The City understood the potential of the adaptive reuse project, and thus supported the redevelopment as it exemplified preservation, conservation, sustainable development, and a community benefit. 


\section{Building Condition}

For adaptive reuse projects, one of the key considerations that could be detrimental to the project is the level of contamination of the site. The level and extent of contamination is unknown, but the soil was contaminated, and clean-up was necessary (Debrnone, n.d.). The building condition prior to redevelopment is seldom referred to in the documents - however, given the scale of the site, the developer had the opportunity to examine numerous buildings on the site to determine which were the most valuable. The buildings chosen to remain intact were structurally sound and only required the upgrades that were mentioned prior.

Overall, the Tannery District is an example of how adaptive reuse can be leveraged to improve the vibrancy of a post-industrial mid-sized city. The investment and innovation that made the Tannery District a hub of knowledge has spurred job creation, and further commercial, institutional and residential development.

\section{2: Kaufman Lofts, Kitchener, ON}

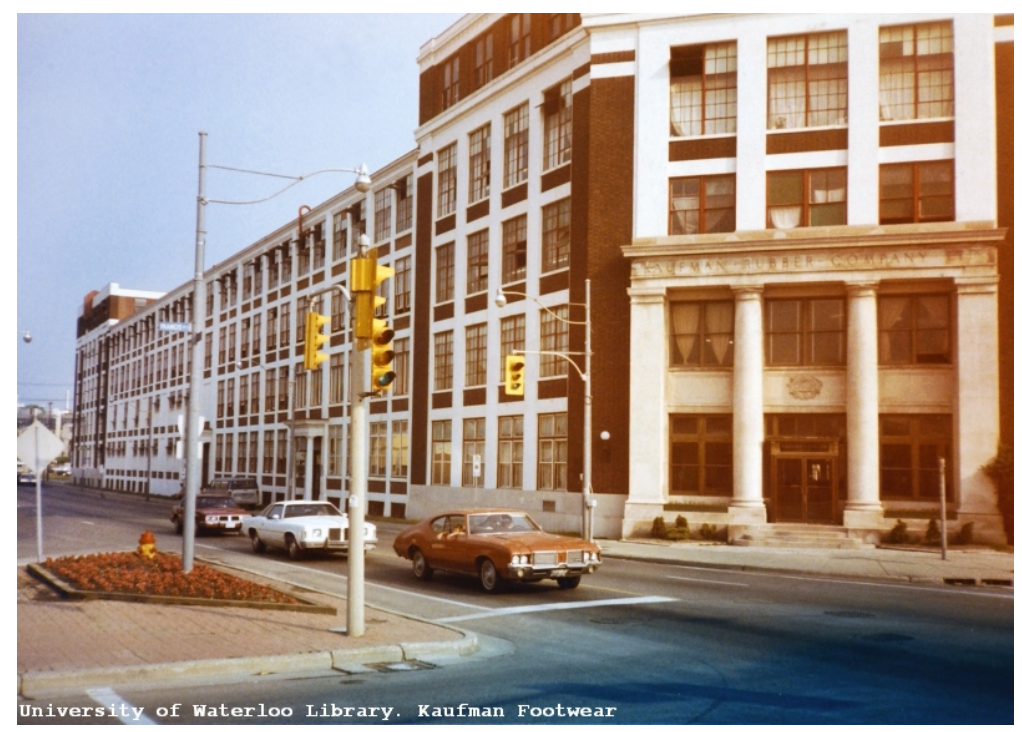

Figure 3. Kaufman Rubber Plant (Doors Closed Waterloo, 2013) 


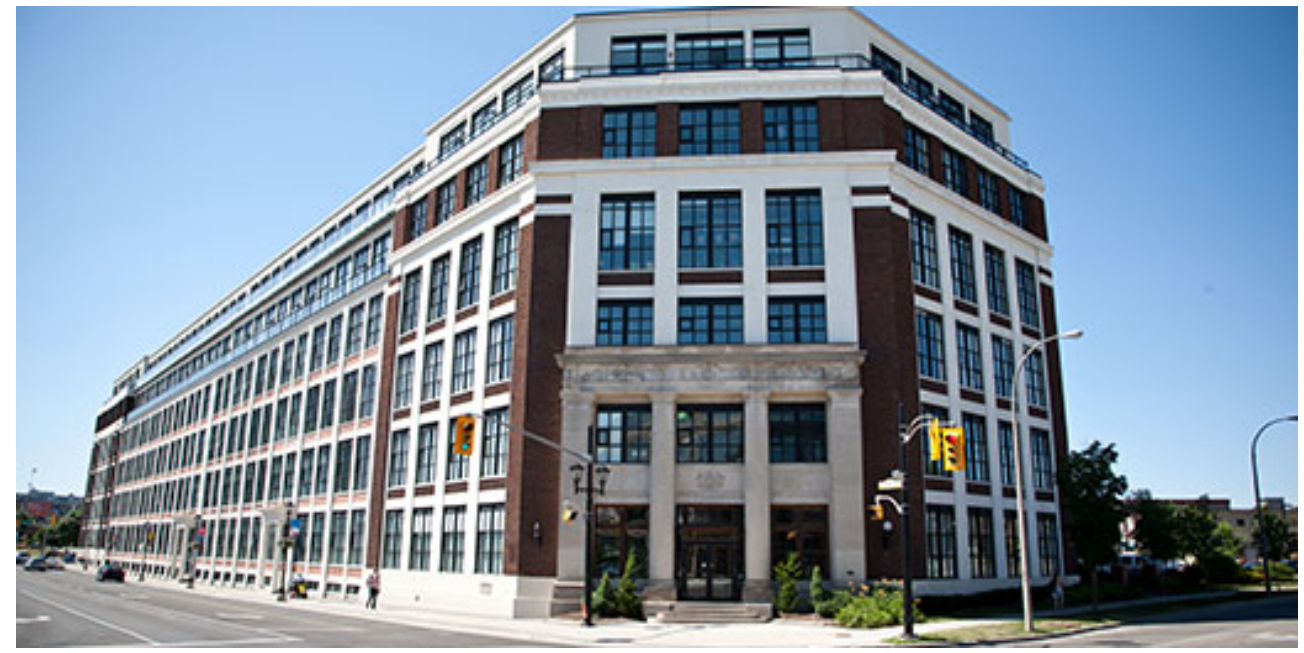

Figure 4. Kaufman Lofts (MHBC, 1998)

\section{Project Overview}

The Kaufman lofts located in downtown Kitchener has many of the same characteristics of the Tannery District especially as they relate to location and legislation. The former industrial building originally built in 1908 as a footwear plant called the Kaufman Rubber Plant was transformed into condominium style lofts (Ryval, 2012). The main attractions for this project were the location, the qualities of the building, and the City's brownfield remediation program (Ryval, 2012).

\section{Sustainability}

The sustainability practices of the Kaufman Lofts are limited to the soil contamination clean-up that was required for redevelopment. Adaptive reuse projects try to implement sustainable development practices, such as LEED certification, etc., however, this building is not LEED certified. Therefore, given the lack of information regarding the structural renovations and additions, it can be assumed the one aspect of sustainability within this specific project is the benefit to the environmental conditions on the site through remediation.

\section{Finance}

The site was purchased by Andrin Homes in 2001 for an unknown value. The cost of the contamination clean-up totaled $\$ 1.5$ million and it took two years (Ryval, 2012). The remediation was funded by the private developer with help from the City of Kitchener and the Region of Waterloo (Ryval, 2012). The estimated redevelopment costs for the project was $\$ 200$ 
million (Ryval, 2012). In addition to financial aid for the clean-up, the developer did not have to pay for development charges. Andrin Homes spoke to the costs of redevelopment and new development by stating that typically, redevelopment is costlier than new development, and the price is harder to predict (Ryval, 2012).

\section{$\underline{\text { Market }}$}

The site was acquired at a time when downtown Kitchener was still experiencing a lack of strong market forces for both commercial and residential spaces. However, due to the City of Kitchener successfully encouraging local institutions such as the University of Waterloo, Laurier University, and McMaster University to locate some of their campuses in the downtown area, there has been an increased demand for both commercial and residential space (Ryval, 2012). When the units first hit the market in 2006 they were sold out in five weeks (Bach, 2010). The typical owners of the loft units are young professionals; the building experiences a high turn around rate but also low vacancy rates, this can be attributed to the movement of young professionals as they enter school, start new careers, and/or meet life partners (Bach, 2010). The units were priced relatively low and have now increased an average of approximately 38 per cent (Bach, 2010). The project would not have experienced the same market characteristics without the relocation of the educational campuses mentioned above. The Kaufman lofts have benefitted from the increase in development and redevelopment in the downtown Kitchener area

\section{Changeability}

The changeability of a site is hard to measure but certain characteristics of a building allow the structure to easily take the form of another use. The Kaufman factory has oversized windows, large open space, and high ceilings (Hamnett \& Whitelegg, 2006). These are all attributes that allow for the successful conversion of the building to a loft units (Hamnett \& Whitelegg, 2006). This type of conversion can be seen in other similar former industrial buildings in Toronto, such as the Tip Top Tailor lofts and Toy Factory lofts.

\section{$\underline{\text { Location/Neighbourhood }}$}

The location was noted as one of the most important components of this project. The lofts are situated at a downtown intersection near the University of Waterloo Regional Campus, and the Downtown Kitchener Health Sciences Campus. The projected growth of these institutional campuses was seen as an opportunity. There are many amenities and resources located around 
the site, as well as growth in commercial space, therefore making it a prime location for residential development (Ryval, 2012). Construction of the Light Rail transit and central transit hub is underway and will be located close to the redeveloped site - this was also one of the components driving investment in the area.

\section{$\underline{\text { Public Interests }}$}

The role of the public was not identified as a major component of this project. However, the redevelopment, similarly to the Tannery District, illustrates a partnership approach in which the developer and City of Kitchener had numerous conversations regarding the project (Ryval, 2012). The City of Kitchener played an integral part in ensuring the project would be a community asset.

\section{$\underline{\text { Legislation }}$}

This project also received the financial grants of the Brownfield Remediation program. Without this financial assistance form the municipality, the project may not have been feasible. The financial contributions made by the municipality are unknown, however, they contributed financially to the remediation and fully subsidized the development charges for this project. To come to fruition, this redevelopment project required an official plan amendment and a zoning by-law amendment (Sugden, 2017). The City of Kitchener voiced their willingness to generally accept any development applications that demonstrated creative redevelopment, innovation, and influenced further investment (Sugden, 2017). The OPA and rezoning from industrial to residential better reflected the current situation of the downtown and the future plans for the area, therefore the applications were accepted without contention.

\section{Building Condition}

For the clean-up, solvents and rubber had to be removed. With regards to the building, the goal was to restore the structures heritage components such as the deco-style wooden doors and windows, concrete frame, and brick exterior façade. Most of the original exterior characteristics were maintained, therefore, the building was in a condition that allowed the developer to do so.

Similarly, to the Tannery District, the Kaufman Lofts is a useful example of adaptive reuse of an industrial building located in the central business district of a mid-sized city. It demonstrates the 
positive impact of proposing end uses that reflect the vision of the neighbourhood, and the principles put forth in the Official Plan.

\section{3: Tudhope Building, Orillia, ON}

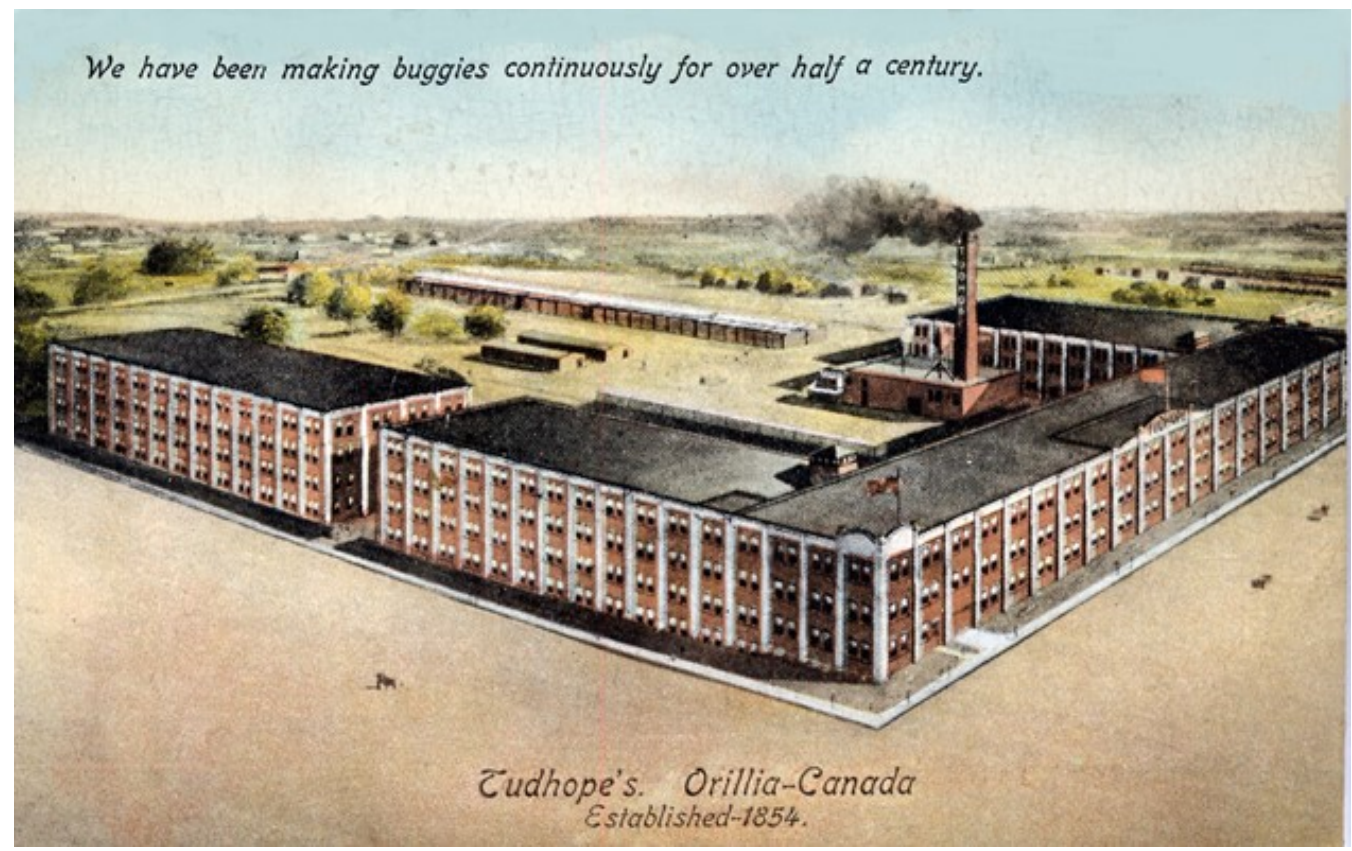

Figure 5.Tudhope Factory Before (Orillia Matters, 2018)

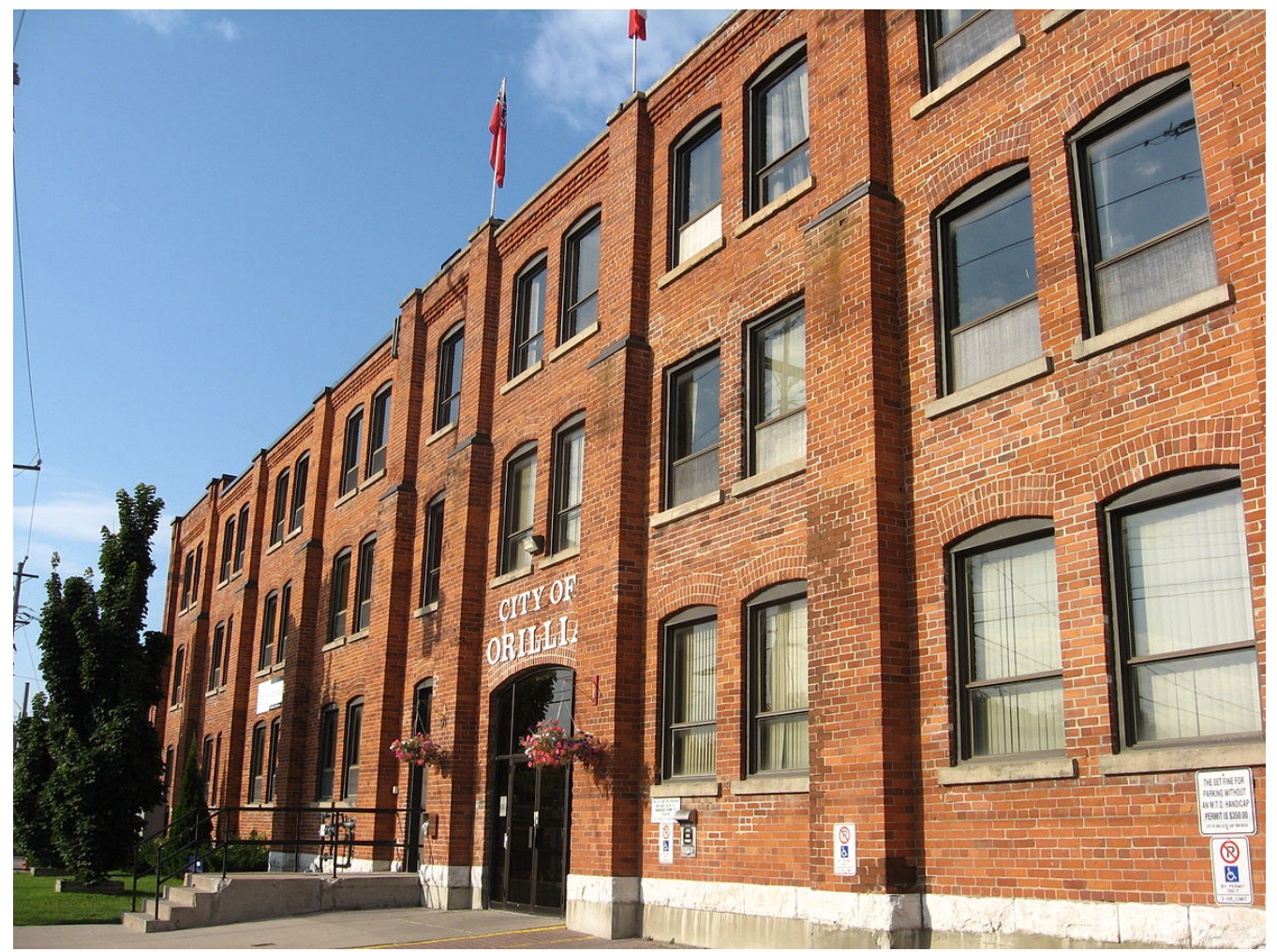

Figure 6. Tudhope Building After (Walker, 2013) 


\section{Project Overview}

The Tudhope Factory was built in 1909, as the Tudhope Motor Company. it manufactured carriages and motor vehicles. It is located near the heart of downtown Orillia. In recent years, the industrial building has been home to numerous uses. In the 1990s it was used by the Ontario Provincial Police (OPP) as their headquarters, and in 1995 it was converted to be used for institutional uses but during renovations in 2004, parts of the structure collapsed. Since the collapse, the building has been rehabilitated and is now home to Orillia City Hall, residential apartment units, Lakehead University satellite campus, and the Orillia Museum of Art and History (Orillia Heritage Centre, 2019).

\section{Sustainability}

There was no information regarding the integration of sustainability measures for this adaptive reuse project.

\section{$\underline{\text { Finance }}$}

The only information found regarding the financial implications of this project include the $\$ 500,000$ rehabilitation costs of the Tudhope building, afforded by the City of Orillia.

\section{Market}

The adaptive reuse of the Tudhope building was undertaken during the 2008 recession. The timing was imperative to the success of this project. The provincial government was active in promoting economic development during the recession, therefore, support existed for the project, as well as hopes the economic landscape would improve, and demand would increase (Sugden, 2017).

\section{Changeability}

The western portion of the Tudhope building is home to the Orillia municipal offices. The eastern half is privately owned and has been developed into upscale apartment units on the upper floors, and Lakehead University classrooms, lab space and a library on the lower levels. The large building has allowed itself to be transformed into a diversity of uses and ownership models. 


\section{Location/Neighbourhood}

The Tudhope building is centrally located within Orillia. Users and residents of the site have access to a wide array of commercial, residential, recreational and institutional uses, and natural features like Lake Couchiching and Veterans Park.

\section{Public Interests}

The purpose of this rehabilitation project and the reason for the City of Orillia in deciding to move their municipal offices to this location was to "create a public space to prominently feature the City's industrial heritage and notorieties" (City of Orillia, 2015).

\section{$\underline{\text { Legislation }}$}

The support and involvement of the local and/or provincial government can have great impact on the feasibility of an adaptive reuse project to be successful. As mentioned, the Tudhope building was home to the OPP for many years. The OPP encouraged the partnering of various municipal and provincial stakeholders, for example, the Mayor's office at the City of Orillia worked to convince the parks and recreation department to assess the remediation requirements and finance the needed remediation (Sugden, 2017). In this case, the OPP was able to influence municipal representatives to take on a leadership role in remediation and redevelopment.

\section{Building Condition}

The renovations primarily focus on repairing and restoring the structures historical architectural features. This included restoring the brick façade, redesigning and renovating the exterior entrance, and transforming the vacant areas on the first floor into exhibit space. These were the main renovations and alterations that were needed to bring the building to code compliance. The Tudhope building adaptive reuse project exemplifies the multiple uses that can inhabit a previously underutilized industrial structure through the years, and most recently simultaneously. Industrial buildings, as mentioned, are typically large structures with vast open space. The Tudhope Building is no exception. The size of the Tudhope building lent itself to be adapted to a mix of uses, such as commercial, institutional and residential units. 


\section{4: Mary Web Centre, Highgate, ON}

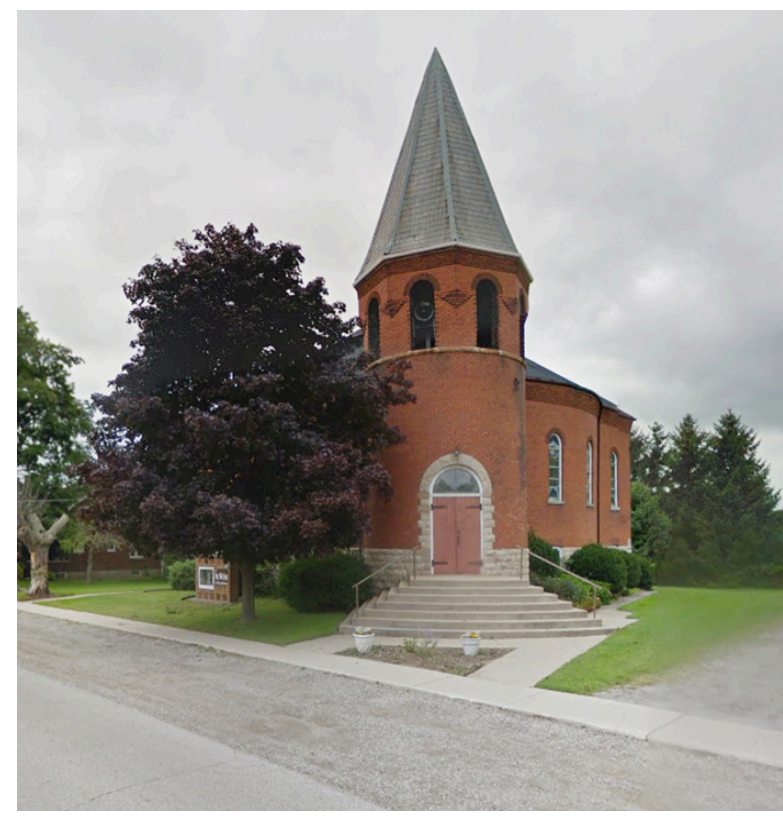

Figure 7. Highgate United Church (Blake, 2012).

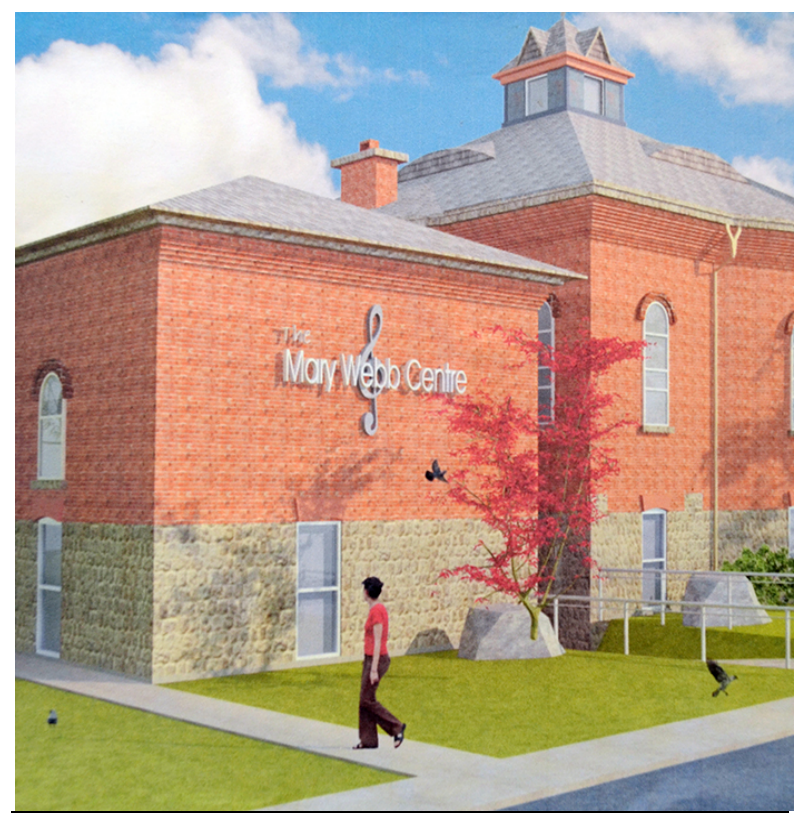

Figure 8. Mary Webb Centre (Blake, 2012)

\section{Project Overview}

The Mary Webb Centre for the Arts is located in Highgate Ontario, a small rural community in the Municipality of Chatham-Kent. This project is an example of adaptive reuse of a former church. It is not a former industrial site but this project can provide insights into how a small rural community in Southwestern Ontario can still produce a successful adaptive reuse project. The church was originally built in 1897 but burned to the ground in 1917 and rebuilt to the same plans in 1918 (Mary Webb Centre, 2018). The final service was held in 2010 (Mary Webb Centre, 2018). Local residents advocated for the conversion of the church into a cultural and community centre that consisted of an art gallery, social hub and reception hall (Mary Webb Centre, 2018). The Mary Webb Centre was formed by a group of community members who were passionate about saving the church.

\section{Sustainability}

Similarly, to above, there were no identified environmental benefits from this project. However, the fate of the building, without the adaptation of it, could have led to demolition, which is adverse impacts on the environment, as mentioned through the assessment of the disadvantages of adaptive reuse. The project demonstrates social sustainability practices by preserving a local landmark that has been a defining feature of the community for over a century (Mary Webb 
Centre, 2018). The church, since its inception, will continue to be used as a place for locals to gather and connect with neighbours and visitors alike.

\section{Finance}

The finances for this project included the costs of the new additions required to ensure the building meets accessibility requirements, and to improve the structure itself to accommodate the new uses. The Mary Webb Centre received a \$250,000 grant from the Canadian Heritage Department, $\$ 100,000$ from the United Church, and \$62,500 from the Municipality of ChathamKent (Morrison, 2018). The new addition costs an estimated $\$ 800,000$. The addition/renovations included converting the nave into a concert hall and the Sunday school room into visual art studios. The addition also included an elevator and accessible washrooms (Morrison, 2018). The grants received from the municipality, Canadian Heritage Department, and the United Church helped fund the required accessibility requirements, convert the spaces to new uses, and improve the structure to ensure a longer lifespan.

\section{Market}

When the Mary Webb Centre acquired the site from the United Church, they had a long-term vision of preserving the landmark and the cultural environment it represented. The business plan focused on the preservation of the site, and the social benefit of adapting it to a community centre (Mary Webb Centre, 2018; Fraser, Semande, Sawchuck, 2011). The project had great support from the community, therefore, the risks were minimal for a few reasons; the costs were not overwhelming, little opposition from the community existed, and it was more attractive than letting the building sit vacant. The business plan emphasized that little actions could lead to big returns, this has become a reality. The centre has had Juno winners perform, and has seen people travel from across the border to attend various events (Mary Webb Centre, 2018). The welldeveloped business plan allowed this project to be feasible and succeed as a community asset.

\section{Changeability}

The conversion of church's has been a recent phenomenon with growing interest in preserving cultural sites and architectural works (Amayu, 2014). Churches can typically lend themselves to specific new uses as they offer open spaces, with different multi-use rooms, and have adequate bathrooms and full kitchens. The interior characteristics of a church can easily be adapted to a 
community centre as the functionality of the two uses are comparable, as is the case here (Amayu, 2014)

\section{Location/Neighbourhood}

The location of the Mary Webb Centre is considered the gateway to Chatham-Kent. It is located at the main-intersection of Highgate and is the main focal point for people travelling through town (Mary Webb Centre, 2018). It is the major landmark of the town, there are no government buildings or large commercial structures. The central and easily identifiable building has contributed to the success of the project. It has become a destination for locals and visitors.

\section{Public Interests}

This project demonstrates the importance of establishing positive relationships with the owner of the building, and other stakeholders such as the local community, the municipality, and in this case the Canadian Heritage Department. The most noteworthy and defining feature of this project is the community benefit. Since it opened, the centre has seen approximately 50 local artists showcase their work in the centres' new facilities (Morrison, 2018). It has become a space for people to connect, showcase their work, and celebrate community.

\section{Legislation}

The Council of Chatham-Kent showed their support for the project by providing a grant for the addition, and by providing an interest free bridge financing loan for the renovations and upgrades

(Fraser, Semande, \& Sawchuck, 2011). The Mary Webb Centre was vocal about their adaptive reuse plans, and therefore were able to secure council support and partnership early on in the process. Unfortunately, no information was found regarding the approvals required for the conversion of the church.

\section{Building Condition}

The building was well-preserved and therefore did not require major alterations. The majority of the needed upgrades were to bring the building up to fire and safety code. This included a new roof, restore stained glass windows, upgraded front porch, a new furnace and air conditioning system, upgraded power supply, fire doors, a new alarm system, and smoke and heat detectors. The lack of structural issues allowed the project to be more cost efficient, than the other applications in this paper. 
The Mary Webb Centre, although not an adaptive reuse of an industrial building, showcases how the needs and voices of the local community can be decide the fate of an underutilized structure. The Mary Webb Centre created a comprehensive business plan that allowed the Council of Chatham-Kent to see the benefits of a converting the vacant church into a community centre.

\subsection{Ambler Boiler House, Ambler, PA}

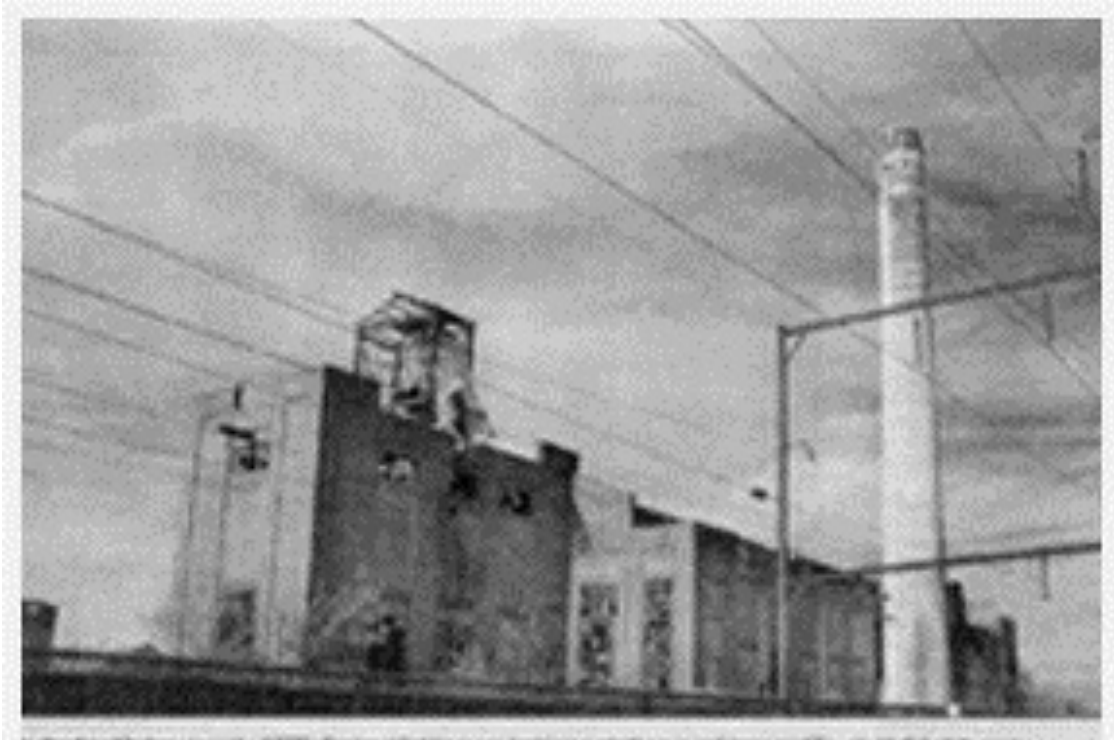

Figure 9. Ambler Boiler Plant (Summit Realty Advisors, 2019)

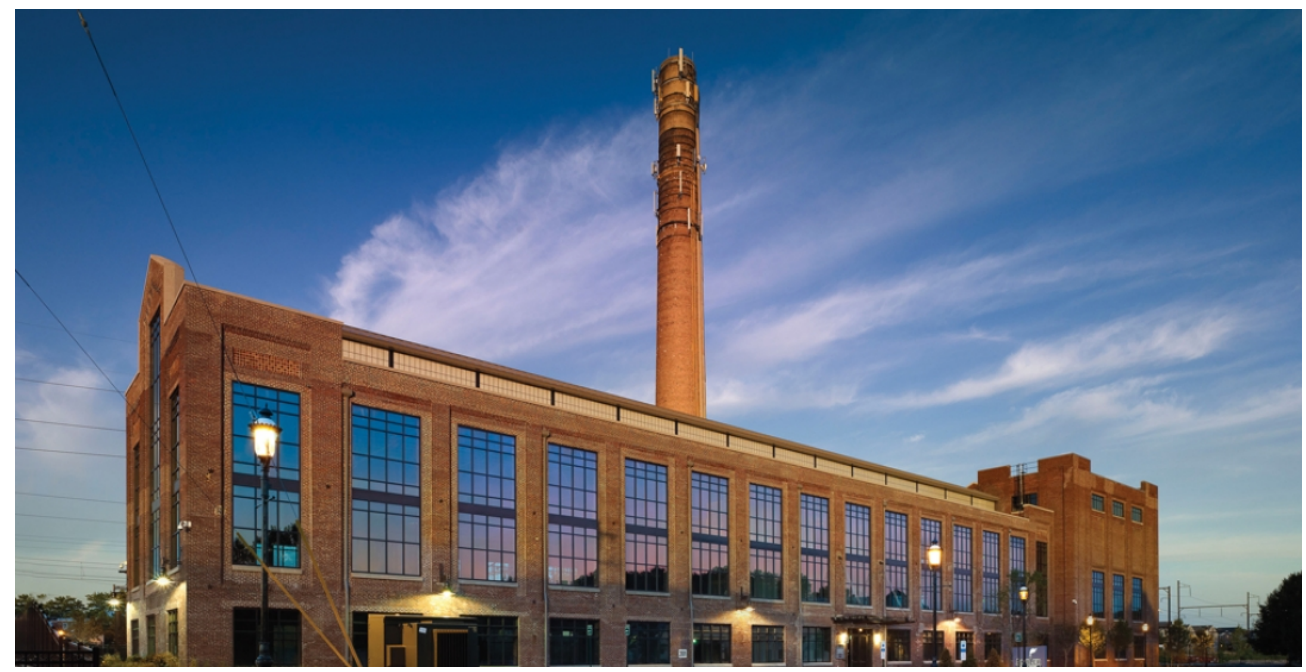

Figure 10. Ambler Boiler House (Summit Realty Advisors, 2019) 


\section{Project Overview}

The Ambler Boiler House, originally the Keasbey and Mattison Boiler House was built in 1887. It was a power-generating station that demonstrated the areas heavy industrial past (Montgomery Awards, 2013). The building was abandoned in the mid-1970s and has since experienced deterioration. The property was purchased in 2000 by Summit Realty Advisors who saw the potential of the site as commercial space. Summit Realty Advisors worked alongside many partners for the remediation and revitalisation of the building, allowing it to successfully adapt to new commercial uses.

\section{Sustainability}

The intent of the project was to recycle and redevelop the industrial structure to exemplify the history of the local community. It successfully preserved an important landmark in the city, eliminated environmental hazards, and enhanced the health, safety and welfare of the community members. The site suffered from significant contamination, including asbestos (Higginbotham, 2013). With the help of the County of Montgomery and the Environmental Protection Agency, the site was subject to remediation. In addition to remediation, the repurposing the building was completed following sustainable development practices. The site now holds LEED platinum certification which means the building demonstrates a high standard of energy and resource efficiency (Higginbotham, 2013). The rehabilitation of the structure also demonstrates a whole building approach, which also focuses on retrofitting solutions "that demonstrate integrated, holistic, and synergistic approaches to energy efficiency" (Whole Building Design Code, 2019, para 2). This adaptive reuse project exemplifies how converting vacant industrial buildings can integrate and demonstrate numerous sustainability components.

\section{Finance}

Summit Realty Advisors received financial support for this project from various partners who saw the benefit of remediating and redeveloping a culturally significant site. Securing financial resources for the remediation was the first step in the process. As mentioned, the remediation of a vacant site can add unanticipated costs to a project, therefore looking to outside sources makes the project more feasible. The asbestos remediation was fully funded by the Pennsylvania Department of the Environmental Protection Agency. In addition to this, the project also received \$2.5 million from EnergyWorks and \$3.5 million from the Department of Housing and Urban Development (Mercier, 2013). The total construction costs of the project was \$16 million. 
Other financial contributors include the Montgomery County, The Montgomery County

Commissioners, Department of Economic Development, and the County Redevelopment Authority.

\section{Market}

When the redevelopment plans were first introduced for the site, the US economy was struggling, resulting in being put on hold for a few years. Construction began in 2011, and with the support of the County of Montgomery and other parties, the project was seen as a catalyst for revitalisation in Ambler. The market conditions posed risks for this redevelopment project but it remained alive due to the interest of numerous agencies and local partners.

\section{Changeability}

The structure was transformed into a class A office building. The building was in a state of deterioration and abandonment; therefore, the major challenge was to maintain the existing industrial characteristics while integrating sustainable building practices and a sophisticated interior office design. The 48,000 square feet building lent itself, with creativity and innovation, to large open space office units.

\section{Location/Neighbourhood}

The Ambler Boiler House is located 40 minutes from Philadelphia with the train station being in close proximity to the site. This location is well served by transit, has easy access to existing roadways and has available utility services. One of the main hopes of this project was to initiate further revitalisation and economic growth for Ambler and the Montgomery county.

\section{$\underline{\text { Public Interests }}$}

There were many stakeholders involved in this project, including elected officials, residents of Ambler, Montgomery Planning Commission, Pennsylvania Department of Environmental Protection, the Redevelopment Authority of Montgomery County, and the Department of Community and Economic Development. It was said that this adaptive reuse project was designed with the best interest of the community. 


\section{$\underline{\text { Legislation }}$}

There was limited information regarding the legislative processes that took place for this project to be approved. However, the strong revitalisation efforts put forth by the Borough and County heavily influenced the success of the redevelopment.

\section{Building Condition}

The main concern of this redevelopment project, once the remediation was completed, were the structural issues and deterioration of the building. The building was nearly in a state of disrepair. It took a total of 760 man-hours of labour, and the removal of 530 cubic yards of contaminate construction materials, to begin the structural upgrades (Higginbotham, 2013). With that being said, even those buildings in a dilapidated state can still be slated for adaptive reuse.

The adaptive reuse of the Ambler Boiler House is a prime example of the effort put forth by various partners who all have a common goal of revitalising a blighted area. The owner, Summit Realty Advisors, alongside government organisations, all contributed to the remediation and redevelopment plan to ensure the project would succeed, and a market would exist for the proposed end use. This adaptive reuse application demonstrates the benefits of engaging with local authorities and integrating sustainable development practices. 


\subsection{SECTION SIX: ANALYSIS}

This section analyzes all the information summarized in Section Five: Case Studies to assess the characteristics of adaptive reuse projects that contribute to the project being successful. The above case studies are all successful examples of adaptive reuse in small to mid-size cities. Two of the case studies, Kaufman Lofts and the Tannery District, are located within less than a $1 \mathrm{~km}$ from each other. The other two Canadian examples, the Tudhope Building and the Mary Webb Centre, demonstrate adaptive reuse in small municipalities. Lastly, the Ambler Boiler House is an exceptional example of adaptive reuse in a small industrial community that was heavily dependent on industrial practices, a characteristic of Southwestern Ontario. The goal of these case studies is to demonstrate how small to mid-size cities in Southwestern Ontario can assess their vacant industrial properties for their potential to be adapted, and the measures they can implement to ensure the success of redevelopment. The following will assess all the characteristics explored above for each project to determine the attributes that should be in place for adaptive reuse to be successful.

\subsection{Sustainability}

For most of the case studies, sustainability practices were not identified as being a major concern of the redevelopment of the site. In some case studies there were clear sustainable characteristics, such as when remediation was required, or in the case of the Ambler Boiler House where sustainable development practices were integrated in the adaptive reuse of the building. However, within these cases, the sustainable characteristics did not hinder or further facilitate the feasibility of converting an underutilized industrial building. There are no sustainable characteristics that need to be in place for an adaptive reuse project to be successful. On the other hand, integrating sustainable development practices into the conversion can improve the support of local authorities and the community. It can also positively impact the funding the project receives. In the case of the Ambler Boiler House, contributions were made by EnergyWorks and the Environmental Protection Agency for the remediation, and to help the project integrate energy efficient technology. This finding is consistent with the literature research in identifying sustainability as predominantly a guiding principle and less of a specific characteristic that is mandatory for a project to be successful. The integration of sustainability practices into the conversion of an industrial building is a benefit, not a necessity. 
In Canada, there is a Green Municipal Fund which provides funds for projects that offer and demonstrate creative solutions to sustainable practices related to brownfields, energy, transportation, waste, and water (FCM, 2019). Municipalities in Southwestern Ontario should be aware of all the potential partnership and funding opportunities for potential adaptive reuse projects that integrate sustainable practices. If municipalities understand the resources available

for certain types of redevelopment projects, they can encourage developers to consider an adaptive reuse project.

\subsection{Finance}

It was determined, through the exploration of adaptive reuse, that there can be unanticipated costs when converting a vacant or underutilized industrial property into a new use. The unanticipated costs are generally with regards to potential contamination and the building condition. From the above examples, it is clear additional sources of funding are available, especially for remediation, and for adaptive reuse of heritage properties or significant historical landmarks. However, it should be noted that not all industrial buildings are designated heritage or have a strong cultural significance. With that being said, the case studies have clearly demonstrated that with promoting the benefits of adapting a vacant or underutilized site, financial resources are available. For example, the Kaufman Lofts and the Tannery District did not have to pay development charges. These charges can drastically increase the cost of a project; therefore, it is important to understand these charges could be subsidized. There was no clear indication of the costs of adaptive reuse projects but if the land can be purchased at a nominal fee, this can create a better rate of return and make the costs of remediation more acceptable. The literature review identified that the economic consideration can be the most important component of the project (Bullen and Love, 2018). The financial implications of adaptive reuse are dependent on the level of contamination, the changeability of the structure, and the building condition, all of which are context specific.

\subsection{Market}

A market for the proposed end use is one of the more important characteristics of the feasibility of an adaptive reuse project. There needs to be people who will occupy or use the site, without users, it will not succeed. In the case of the Tannery District, the developer was aware Communitech was interested in being a tenant. The developer was also aware the City of Kitchener was investing in start-ups in the tech industry to help encourage further occupancy. 
These two factors allowed the developer to move forward with the redevelopment plans confidently. The situation is similar for the Kaufman Lofts. The developer understood the City of Kitchener was encouraging educational institutions to locate in the Kitchener's central business district, and therefore, they predicted a need for residential units in that neighbourhood.

For the Tudhope project and the Mary Webb Centre little information was found regarding the market demand. However, for both these projects, the building was in decent condition, lending itself to be a consideration for businesses or organisations looking at relocating (the Orillia City Hall), or interested in creating new commercial or residential units, or a community centre. The relocation of Orillia City Hall to the Tudhope Building influenced the commercial, institutional and residential uses on the site. The Mary Webb Centre designed a well-developed business plan identifying how transforming the site into a community centre would be a community asset, in which they were correct. The Mary Webb Centre sought out a market for the adaptive reuse. Lastly, the Ambler Boiler House was redeveloped to attract further investment in the area. The market for the proposed commercial uses of the site is unclear, however, the proximity to the train station and to Philadelphia provided potential for a strong market.

Tan et al (2018) stated the feasibility of an adaptive reuse project depends on the needs of the local community and the end use of the building. Being aware of potential market influences, positive and negative, is necessary to understand the feasibility of adaptive reuse of vacant/underutilized industrial sites.

\subsection{Changeability}

The changeability characteristics of adaptive reuse are important components for the feasibility of an industrial building to convert to a new use. Within the literature review it was identified that changeability is one of the most important factors in adaptive reuse. It was explained that the structure needs to be easily adapted to a new use for the project to be successful (Ball, 2002; Lute \& Marincu, 2016; Louw, 2015). If the structure of the building requires a lot of exterior and interior renovations it could incur additional and unanticipated costs. Therefore, an assessment of the additions and alterations needed to allow the building to conform to a new use, and to comply with codes, should be conducted. From the case studies, little information exists regarding the changeability of the building, but typically, larger open spaces, large windows, and high ceilings provided greater ability to convert to a number of uses. These are the qualities municipalities or 
developers could look for when assessing the feasibility of adapting industrial buildings to new uses.

\subsection{Location}

The Tannery District, Kaufman Lofts, Tudhope Building, and the Mary Webb Centre are all centrally located within their respective municipalities. The centrality of these sites has contributed to their success, as found in the secondary research. These sites were able to benefit from nearby amenities, existing services, and access to various modes of transportation. Central locations have consistently been used to attract institutional, commercial, recreational, and residential uses; adaptive redevelopments are no exception to this. Additionally, Ball (2002) stated that location needs to be considered within the context of local economic and social factors to best understand how the new use will interact with the surrounding neighbourhood. Location should be a key consideration when analyzing the feasibility of adaptive reuse. Centrally located industrial buildings should be seen as more feasible than those located on the outer ring of the municipality.

\subsection{Legislation}

The legislative characteristics impact the feasibility of adaptive reuse by way of the support by the local municipality. If the proposed redevelopment scheme reflects the policies of the local municipality there will be more support from the authorities. The redevelopment of the Tannery buildings and the Kaufman factory reflected the visions for the downtown neighbourhood set forth in the Official Plan. The City of Kitchener also has a brownfield redevelopment program that encouraged revitalisation of former manufacturing sites. The legislation of a given municipality should encourage and incentivize the redevelopment and adaptation of vacant industrial buildings. Yung and Chan (2015) found that the cost and time of approval processes can result in the project being inefficient and no longer feasible. Therefore, government assistance programs, such as those mentioned above, improve the legislative processes to decrease the impact of timely and costly processes. If the legislation is promoting the redevelopment of these sites, the approvals process would occur more fluently, it would also be less costly, and timely. The legislation is made with much consideration of the public's interest, therefore if the adaptive reuse project respects the local policies this has the potential in resulting from less opposition and more support from the public. 


\subsection{Public Interests}

The case studies did not explicitly speak to how the public was engaged and involved in the projects. However, some of the projects, such as the Tannery District and the Mary Webb Centre, spoked quite extensively to the impact of the redevelopment on the local community. The Tannery district engaged with potential tenants of the site, as part of their redevelopment plan. The feedback from this engagement impacted the exterior and interior design of the redevelopment. They wanted the project to best reflect the potential users - this should be a lesson for all developers for new and rehabilitated projects. The Mary Webb Centre also looked to the community when creating the business plan for the redevelopment of the church. The Centre wanted to create a community facility that brought together local residents, business owners, and visitors. This was done by engaging with and involving the community that had been supportive of the redevelopment since the closure of the church.

The public interest can be impactful towards the feasibility of an adaptive reuse project. Resistance from the public can result in delays and even the project being denied by the municipality. Therefore, it is imperative the person responsible for the adaptive reuse project engages and involves the community in the decision-making process to gain their support because with their support the project has a greater chance of being successful. This sentiment was reflected in the literature by Tan et al. (2018), Yung and Chan (2012) and Aigwi et al. (2018) who state preservation can improve sense of place and increase the vibrancy of a community.

\subsection{Building Condition}

Based on the information gathered, it is hard to determine the exact building conditions that can impact the feasibility of an adaptive reuse project. It can be concluded that the less upgrades and additions required to rehabilitate the building for a new use, the more feasible the project will be. As mentioned through the literature review the building condition and associated costs depend on the age, heritage value, size, accessibility and design (Ball, 2002). In addition, depending on the needed upgrades, at a certain point one would need to consider if the upgrades are more manageable and cost-efficient compared to demolition. 


\subsection{SECTION SEVEN: RECOMMENDATIONS AND CONCLUSION}

Adaptive reuse of vacant industrial buildings is a viable option for municipalities to foster revitalisation and increased investment in their locale. Southwestern Ontario was hit particularly hard by the economic events of 2008/2009, leaving the area with a high volume of vacant and underutilized industrial sites. The predominant economic activity of Southwestern Ontario was manufacturing, it is a part of the urban landscape, it is a part of the history of the area, and now, it reminds residents of better economic days. The municipalities in Southwestern Ontario should look to adaptive reuse as an opportunity to improve their urban landscape, utilize existing infrastructure and services, and create a strong sense of community through preserving the history of the town.

The case studies explored throughout Section Five provide examples as to how adaptive reuse can transform a site, a neighbourhood, and a community. The case studies were analyzed based on eight characteristics that were found to be the most defining features of redevelopment projects. By identifying the components of these characteristics, it was clear as to the factors that can both hinder and facilitate the success of adaptive reuse. Section Six summarized the key components of the case studies through the eight characteristics to help formulate recommendations to municipalities. These recommendations will help guide municipalities in Southwestern Ontario with the decisions they can make to encourage adaptive reuse projects.

\section{Recommendation \#1}

\section{Create a database of all vacant and underutilized industrial properties, identifying the} location, the services and utilities available to the site, and the year it was last used and the original use.

The database can be created at either a municipal or county level. If the county created a database, they could work with municipalities to identify the most feasible vacant industrial properties within the county, to better inform potential developers. The database should also indicate the condition of the site and potential contamination. Municipalities should work with the county to identify which of their sites are contaminated and/or located near utilities and existing infrastructure. To best utilize resources municipalities could start by focusing on centrally located sites and move outward. They should provide the county with the information as soon as it is collected. It is recommended the county make this information publicly accessible displayed on an interactive mapping system. By identifying all the vacant sites, the municipality 
and county could become incentivized to then focus on potential resources such as funding options or partnerships to revitalise the most feasible sites.

\section{$\underline{\text { Recommendation \#2 }}$}

\section{Update municipal planning policies to reflect the redevelopment of the vacant and} underutilized sites by considering how these sites can be better utilized.

Municipal and county (when applicable) planning policies should promote revitalisation and redevelopment of brownfield sites. If vacant sites are rezoned from industrial to a new land use that better fits within the context, this could incentivize developers. It also demonstrates local authorities are forward-thinkers. By having land use policies that identify the future growth or future expectations of a vacant site, developers could view this as having their support, and the community’s support.

\section{$\underline{\text { Recommendation \#3 }}$}

\section{Implement a brownfield redevelopment financial incentive program to encourage} developers to take on adaptive reuse projects. Create a legislative framework that minimizes the risks and maximizes the reward (i.e. increased funding for redevelopment as opposed to new development).

Municipalities and counties should implement redevelopment programs such as those used in the case of the Kaufman Lofts and the Tannery District. Both the City of Kitchener and the Region of Waterloo had programs to help developers revitalise brownfield sites. The Region of Waterloo offers a Development Charge Exemption Program for brownfield sites and the City of Kitchener has the Brownfield Financial Incentive Programs which provides funding for environmental assessments, site clean-up and other costs. This recommendation is not to say certain municipalities do not already offer such incentives, however, those that do offer programs should assess the progress to ensure it is the best program for their context.

\section{$\underline{\text { Recommendation \#4 }}$}

Conduct a market analysis that identifies the best potential uses of the sites in the database, start with the sites that are centrally located. The market analysis should identify the uses that are needed in specific areas.

Lastly, through the database information gathering period, municipalities and the county will be aware of their most feasible, centrally located vacant sites. This should encourage them to 
conduct market analysis for those sites. Taking into consideration financial and staffing resources, municipalities could opt to do a market analysis for only three of their most attractive and feasible sites.

These recommendations are strictly for municipalities and counties in Southwestern Ontario, they speak to certain elements local authorities can implement to attract developers to consider adaptive reuse, as opposed to new construction. Adaptive reuse is a sustainable development method and should be regarded as a benefit to the community, the economy, and the environment. It is a development scheme focused on conservation and preservation. Southwestern Ontario is scattered with vacant industrial buildings that are in need of rehabilitation and revitalisation. Therefore, the recommendations provided speak to how municipalities can encourage revitalisation and investment in their communities.

Adaptive reuse can be a feasible redevelopment application in Southwestern Ontario, as made clear through the case studies. However, municipalities and counties should pay attention to demographic changes, market characteristics, and their legislative environment. This will allow them to effectively encourage the right type of revitalisation. Local authorities need to demonstrate their willingness to work with developers to ensure their redevelopment scheme will be profitable and successful for the community, economy, and environment. 
APPENDIX A

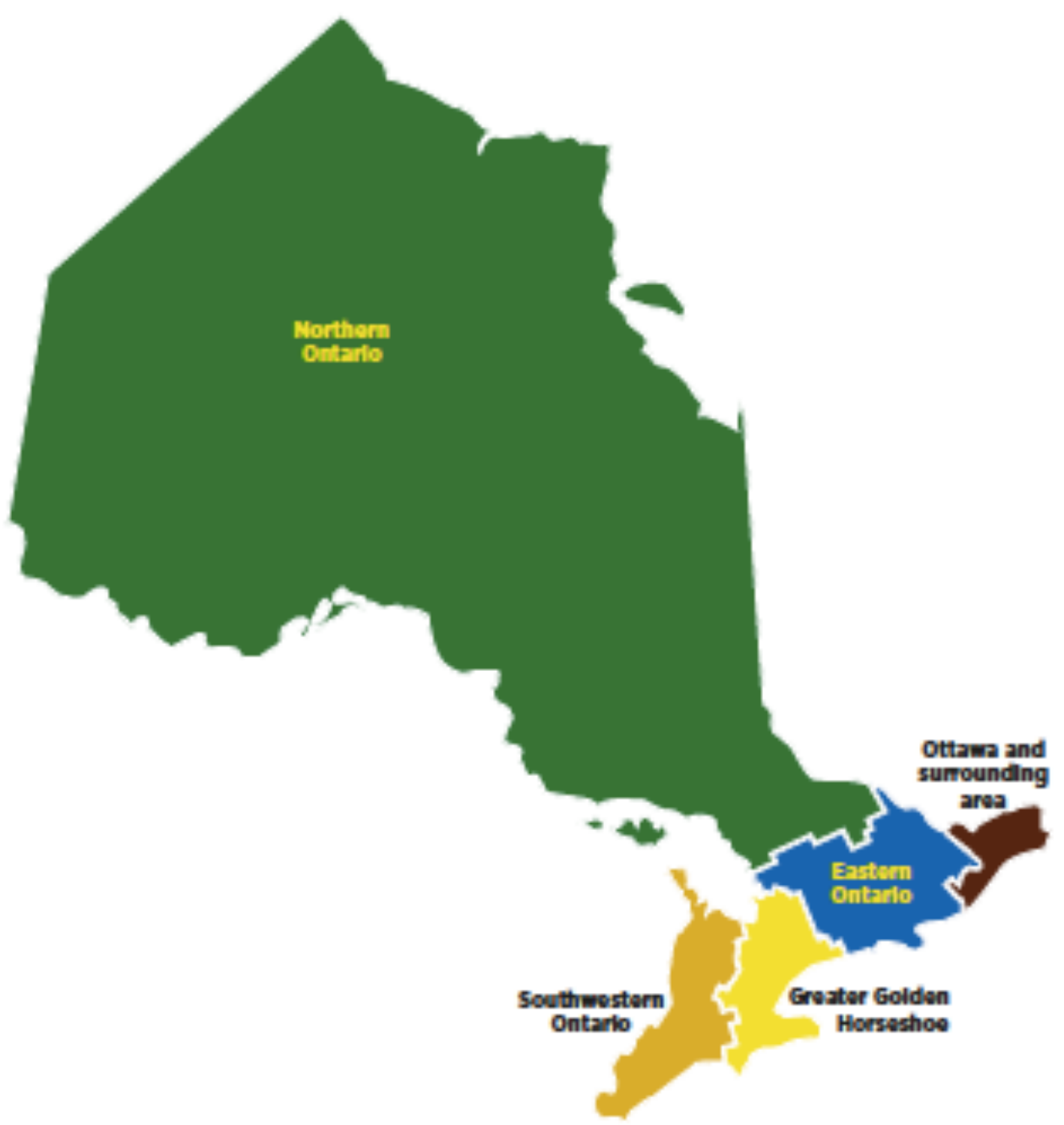

Context Map (Eisen \& Ames, 2016) 


\section{References}

Aigwi,I.E., Egbelakn, T., \& Ingham, J. (2018). Efficacy of adaptive reuse for the development of underutilised historical building: Towards the regeneration of New Zealand's provincial town centres. International Journal of Building Pathology and Adaptation, 36 (4), $385-$ 407.

Amayu, E. (2014). New Uses for Old Churchs: An Examination of the Effects of Planning Regulations on the Adaptive Reuse of Church Buildings. Master's Thesis, Kingston, ON.

Ball, R. 1999. Developers, regeneration, and sustainability issues in the reuse of vacant industrial buildings. Building Research and Information, 27 (3), 140-148.

Ball. R. (2002). Re-use potential and vacant industrial premises: revisiting the regeneration issue in Stoke-on-Trent. Journal of Property Research, 19 (2), pp. 93-110

Bach, B. (2010). The Kaufman Lofts In Kitchener Waterloo. Kitchener Condos: KW Commercial - Keller Williams Golden Triangle Realty. Accessed online https://www.slideshare.net/benbach/the-kaufman-lofts-in-kitchener-waterloo

Blake, J. (2012). Mary Webb Centre Thriving. The Chatham Voice. Accessed online https://chathamvoice.com/2016/10/12/mary-webb-centre-thriving/

Bernier, L. (2013). Many Southwestern Ontario cities dealing with growing numbers of empty or abandoned structures. The Chatham Daily News.

Bullen, P., \& Love, P. (2011). A new future for the past: a model for adaptive reuse decisionmaking. Built Environment Project and Asset Management, 1(1), 32-44

Cantell, S.F. (2005). The Adaptive Reuse of Historic Industrial Buildings: Regulation Barriers, Best Practices, and Case Studies (Major Research Paper). Virginia Polytechnic Institute and State University, Blacksburg, Virginia. 
City of Kitchener. (n.d.). The Tannery District: Rehabilitation / Adaptive Reuse Award.

Accessed online

https://www.kitchener.ca/en/resourcesGeneral/Documents/DSD_ECDEV_TheTanneryDi

strict.pdf

City of Kitchener \& Region of Waterloo. (2016). Brownfields Financial Incentive Program: Joint Tax Increment Grant (TIG). Accessed online https://www.kitchener.ca/en/resourcesGeneral/Documents/DSD_ECDEV_Joint-TIGApplication-fillable-April2016.pdf_

Cross, E. (2001). Proceedings from $12^{\text {th }}$ Headwaters Conference: What is Sense of Place? Western State College, Gunnison Colorado.

De Bono, N. (2017). Vacant sites could lose property tax rebates in London. The London free Press.

Debrone, C. (n.d.). Redevelopment of Kitchener's Tannery District wins best overall project. Kitchener Citizen. Accessed online http://www.kitchenercitizen.com/tannery.html_

De Sousa, C., Wu, C., \& Westphal, L. (2009). Assessing the Effect of Publicly Assisted Brownfield Redevelopment on Surrounding Property Values. Economic Development Quarterly 23(2), 95-110.

Doors Closed Waterloo. (2013). Kaufman Footwear. Closed Doors: Opened Through Archives. Accessed online https://doorsclosedwaterloo.wordpress.com/kaufman-footwear/

Douglas, J. (2006). Building Adaptation. Butterworth-Heinermann, London.

Eisen, B,. \& Ames, J. (2016). The Five Solitudes of Ontario: A Regional Analysis of Labour Market Performance in Post-Recession Ontario. The Fraser Institute, Vancouver, British Colombia. 
Evergreen Brickworks. (2017). Our City, Our Spaces: Adaptive Reuse for Community Benefit. Accessed online https://www.evergreen.ca/downloads/pdfs/2017/Our_City_Our_Spaces_Evergreen_Repo rt.pdf

Fraser, S., Semande, E., and Sawchuck, M. (2011). Ontario Heritage Trust: Heritage Matters. Accessed online https:/www.heritagetrust.on.ca/user_assets/documents/HM-May-2011ENG.pdf

Hamnett, C., \& Whitelegg, D. (2006). Loft conversion and gentrification in London: from industrial to postindustrial land use. Environment and Planning A, 39,106-124.

Hayek, M., Arku, G., \& Gilliland, J. (2010). Assessing London, Ontario’s brownfield redevelopment effort to promote urban intensification. Local Environment, 15(4), 389402.

Higginbotham, J. (2013). From power plan to office: Ambler Boiler House Conversion. Building Design and Construction. Accessed online https://www.bdcnetwork.com/power-plantoffice-ambler-boiler-house-conversion

Jevremovic, L., Vasic, M., \& Jordanovic M. (2012). Aesthetics of industrial architecture in the context of industrial buildings conversion. Presented at PhiDAC 2012.

Louw, M.P. (2015). The adaptive reuse of industrial structures: Revisiting the Thesen Islands power station project in South Africa. Journal of Engineering Design and Technology 4 (4), $920-940$.

Lute, M. and Marincu, A. 2016. Proceedings from $16^{\text {th }}$ International Multidisciplinary Scientific GeoConference SGEM 2016: Green Development of City Areas by Using Industrial Heritage and Modern Approaches. Albena, Bulgaria: Green Design and Sustainable Architecture. 
Mesthrige, J.W., Wong, J.K.W., \& Nga Yuk, L. (2018). Conversion or redevelopment? Effects of revitalisation of old industrial buildings on property values. Habitat International 73, 53-64.

Mercier, D. (2013). Generating New Life At The Ambler Boiler House. Hidden City Philadelphia. Accessed online https://hiddencityphila.org/2013/03/generating-new-life-atthe-ambler-boiler-house/

MHBC Planning. (1998). Kaufman lofts. Accessed online http://www.mhbcplan.com/usercontent/SelectedWorks/KaufmanLofts/Kaufman-LoftsDownload-Sheet.pdf

Ministry of Municipal Affairs and Housing. (2007). A Practical Guide to Brownfield Redevelopment in Ontario. Accessed online http://www.ontla.on.ca/library/repository/mon/19000/276854.pdf

Mohamed, R., Boyle, R., Yang, A.Y., \& Tangari. (2017). Adaptive reuse: a review and analysis of its relationship to the 3 Es of sustainability. Facilities, 35 (3/4), 138-154.

Mora Masonry. (20190. The Lang Tannery. Accessed online https://moramasonry.com/project/lang-tannery

Morrison, T. (2018). We're here to stay: Highgate's Mary Webb Centre gets $\$ 800,000$ addition. LeaderPost.

Orillia Matters. (2018). Following fire in 1909, Tudhope building was rebuilt in just 79 days! https://www.orilliamatters.com/postcard-memories/following-fire-in-1909-tudhopebuilding-was-rebuilt-in-just-79-days-956266

Pender, T. (2015). Historic tannery building to be saved. The Record. Accessed online https://www.therecord.com/news-story/6213890-historic-tannery-building-to-be-saved/ 
Petković-Grozdanovića, N., Stoiljković, B., Keković, A., \& Murgul, V. (2016). The possibilities for conversion and adaptive reuse of industrial facilities into residential dwellings. Procedia Engineering, 165, 1836-1844.

Radwanski, A. (2018). The long, slow decline of the nation's industrial heartland. The Globe and Mail.

Ryval, M. (2012). From Brown to Gold: The trials, tribulations and rewards of development brownfields. Ontario Home Builder.

Schilling, J.M. (2002). The Revitalisation of Vacant Properties: Where Broken Windows Meet Smart Growth. International City/County Management Association, Washington, D.C.

Schilling, J. and Logan, J. (2008). Greening the Rust Belt: A Green Infrastructure Model for Right Sizing America's Shrinking Cities. Journal of the American Planning Association, 74 (4), 451-466.

Sugden, E. (2017). The Adaptive Reuse of Industrial Heritage Buildings: A Multiple-Case Studies Approach. Thesis submitted to University of Waterloo, Waterloo, ON.

Summit Realty Advisors. (2019). History of Ambler Boiler House. Accessed online http://www.summitrealtyadvisors.com/history/

Tam, V.W.Y., \& Hao, J.J.L. (2018). Adaptive reuse in sustainable development. International Journal of Construction Management.

Tan, Y., Shuai, C., \& Wang, T. (2018). Critical Success Factors (CSFs) for the Adaptive Reuse of Industrial Buildings in Hong Kong. International Journal of Environmental Research and Public Health, 15, 1-19.

Walker, M. (2013). Orillia City Centre sprinklers malfunction, flooding municipal offices. CTV News Barrie. Accessed online https://barrie.ctvnews.ca/orillia-city-centre-sprinklersmalfunction-flooding-municipal-offices-1.1340751 
Walljes, I., \& Ball, R. (1997). Exploring the realities of the sustainable city through the use and reuse of vacant industrial buildings. European Environment, 7, 194-202

Whole Building Design Code. (2019). Implementing Deep Retrofits: A whole building approach. Accessed online http://www.wbdg.org/continuing-education/femp-courses/fempfts 19

Wilson, C. (2010). Adaptive Reuse of Industrial Buildings in Toronto, Ontario (Major Research Paper). Queens University, Kingston, Ontario.

Yung, E.H.K., and Chan, E.H.W. (2012). Implementation challenges to the adaptive reuse of heritage buildings: Towards the goals of sustainable, low carbon cities. Habitat International, 36, 352-361. 